

\section{WATER RESOURCES PROTECTION AND INFORMED DECISION MAKING AN EXAMPLE OF THE DAGU AQUIFER IN QINGDAO, PEOPLE'S REPUBLIC OF CHINA}

Frank Radstake, Yongqiang Qi, Jehangir F. Punthakey, and Lihong Yang 
(C) 2017 Asian Development Bank

6 ADB Avenue, Mandaluyong City, 1550 Metro Manila, Philippines

Tel +632632 4444; Fax +6326362444

www.adb.org

Some rights reserved. Published in 2017.

ISBN 978-92-9257-831-2 (Print), 978-92-9257-832-9 (e-ISBN)

Publication Stock No. TCS178799-2

DOI: http://dx.doi.org/10.22617/TCS178799-2

The views expressed in this publication are those of the authors and do not necessarily reflect the views and policies of the Asian Development Bank (ADB) or its Board of Governors or the governments they represent.

ADB does not guarantee the accuracy of the data included in this publication and accepts no responsibility for any consequence of their use. The mention of specific companies or products of manufacturers does not imply that they are endorsed or recommended by $\mathrm{ADB}$ in preference to others of a similar nature that are not mentioned.

By making any designation of or reference to a particular territory or geographic area, or by using the term "country" in this document, $\mathrm{ADB}$ does not intend to make any judgments as to the legal or other status of any territory or area.

This work is available under the Creative Commons Attribution 3.0 IGO license (CC BY 3.0 IGO)

https://creativecommons.org/licenses/by/3.0/igo/. By using the content of this publication, you agree to be bound by the terms of this license. For attribution, translations, adaptations, and permissions, please read the provisions and terms of use at https://www.adb.org/terms-use\#openaccess

This CC license does not apply to non-ADB copyright materials in this publication. If the material is attributed to another source, please contact the copyright owner or publisher of that source for permission to reproduce it. $\mathrm{ADB}$ cannot be held liable for any claims that arise as a result of your use of the material.

Please contact pubsmarketing@adb.org if you have questions or comments with respect to content, or if you wish to obtain copyright permission for your intended use that does not fall within these terms, or for permission to use the ADB logo.

Notes:

In this publication, “\$” refers to US dollars.

ADB recognizes "China" as the People's Republic of China.

Corrigenda to ADB publications may be found at http://www.adb.org/publications/corrigenda 


\section{Contents}

Table and Figures $\quad$ iv

Foreword $\quad \mathrm{v}$

Acknowledgments vi vi vil vis

About the Authors vii

Abbreviations viii

1 Groundwater: A Strategic Water Resource 1

2 Informed Decision Making: Facts versus Fiction 6

3 Sustainable Yields: Key to Water Resources Planning 8

4 Water Quality Concerns: Nonpoint Source Pollution Threats 12

5 Nonpoint Source Pollution Control: Integrated Solutions 16

6 Main Findings: Information Key to Decision Making 20

Appendix: Description of the Applied Software Packages 22 


\section{Table and Figures}

\section{Table}

Average Annual Water Balance of the Dagu Aquifer, January 2009-August 2014

\section{Figures}

1 Overview of the Dagu Aquifer 2

2 Fertilizer Usage and Nitrate Pollution in Dagu Basin 5

3 Fence Diagrams with Related Base Map in the Dagu Database $\quad 7$

4 Model Calibration with Historic Groundwater Levels, December 2008-December 2013

5 Model Calibration with Historic Groundwater Levels, January 2014-August $2014 \quad 9$

6 Modeling Impacts of Different Pumping Scenarios 10

7 Modeling Impacts of Different Climatic Scenarios 11

8 Schematic Movement of Fertilizers through Soil into Groundwater $\begin{array}{ll}\text { and Surface Water Systems } & 12\end{array}$

9 Nitrate Hot Spots in the Dagu Aquifer (Based on Monitoring Data for 2007-2013) 14

10 Estimated Volume and Location of Groundwater to Be Remediated 16

11 Land Use and Nitrate Leaching Estimates 17

12 Nitrate Leaching for Different Crops 19 


\section{Foreword}

T T ater security has become a key policy priority for most countries in Asia-and the People's Republic of China is no exception. Many local governments in the country are struggling to balance economic growth with the proper protection and management of their water and natural resources. As economies grow, industries, farmers, and domestic water users demand more water. Reliable water supply is essential to sustain economic growth and food production. At the same time, maintaining healthy rivers and ecosystems, and environmental protection are also recognized as key to sustainable development. Uncertainties due to a changing climate form an additional critical challenge that needs to be taken into account.

From August 2013 to December 2015, the Asian Development Bank provided support to the Qingdao Municipal Government for the preparation of a groundwater resources plan for the Dagu aquifer, an important water source for Qingdao City. The municipal government recognized that it needed information and process to reach a common understanding among various stakeholders regarding (i) baseline information for the Dagu groundwater resources, (ii) options for the treatment of groundwater pollution, and (iii) the needed planning for the management and protection of the Dagu groundwater resources.

The experiences and findings of the study, in particular the applied modeling technologies, proved valuable contributions for the Qingdao Municipal Government to make informed decisions for the planning of its water resources. The technical assistance project provided an operational information system, which proved critical to demonstrate the management options available for the municipal government to improve the protection of its groundwater resources. It illustrated the complexity of achieving a good understanding of the processes affecting groundwater quantity and quality. Further, it confirmed that there is no one-size-fitsall approach for sustainable groundwater resources management. The modeling exercise also provided a solid justification for preferred and effective nutrient management alternatives to reduce groundwater pollution.

The Asian Development Bank is hopeful that these experiences and lessons learned can also provide guidance for other local governments which are facing similar challenges. Although the technical assistance project illustrated that there is no one solution that applies to all situations, it did provide a number of technologies and approaches that should be the basis for all decision-making processes in planning for water resources development.

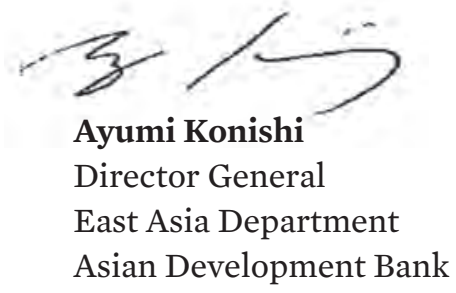




\section{Acknowledgments}

This report is the outcome of the technical assistance project called Dagu Groundwater

1 Rehabilitation and Protection, with funding from the Asian Development Bank and the Government of the People's Republic of China. We highly value the excellent leadership and inspiration of the Qingdao Municipal Government for initiating this study.

We would like to acknowledge and express our appreciation for the extensive work and achievements of a large number of national and international experts from Qingdao Municipal Government and the technical assistance consultants. In particular, we would also like to thank all the members of the project management office of the Qingdao Hydrological Bureau, who worked effortlessly to prepare and implement the day-to-day tasks that were necessary for the successful completion of the technical assistance project.

Thanks are also due to a number of peer reviewers and contributors to this publication, including the technical peer reviewers Eric Quincieu, Water Resources Specialist in the Southeast Asia Department, and Garrett Kilroy, Evaluation Specialist in the Independent Evaluation Department. Outstanding support for the administration and publication preparation of the technical assistance project was provided by Angelica Sebastian-Mercader, Senior Operations Assistant in the East Asia Department, and Joy Quitazol-Gonzalez, staff consultant. Valuable guidance and continuous support were provided by the Management, the East Asia Department, and the Department of External Relations whose staff assisted in disseminating the results of the study.

Finally, we would like to thank the team of the Water Sector Group for their strong support and for financial assistance from the Water Financing Partnership Facility for finalizing this publication. 


\section{About the Authors}

Frank Radstake is Principal Environment Specialist, East Asia Department, Asian Development Bank, Manila, Philippines.

Yongqiang Qi is Vice President, Beijing Water International-Water and Environmental Consultants, Beijing, People's Republic of China.

Jehangir F. Punthakey is Director-Groundwater, Ecoseal Developments, Roseville, Australia.

Lihong Yang is Senior Technical Manager, Beijing Water International-Water and Environmental Consultants, Beijing, People's Republic of China. 


\section{Abbreviations}

$\begin{array}{ll}\text { ha } & \text { hectare } \\ \mathrm{kg} & \text { kilogram } \\ \mathrm{km} & \text { kilometer } \\ \mathrm{km}^{2} & \text { square kilometer } \\ \mathrm{l} & \text { liter } \\ \mathrm{m} & \text { meter } \\ \mathrm{m}^{3} & \text { cubic meter } \\ \mathrm{mm} & \text { millimeter } \\ \text { NLEAP } & \text { Nitrate Leaching and Economic Analysis Package }\end{array}$




\section{Groundwater: \\ A Strategic Water Resource}

TT Tater security. Many local governments in the People's Republic of China are struggling to ensure a water-secure future for their residents. Economic growth and subsequent increasing water demands, combined with uncertainty of the impacts of climate change, are forcing local governments to reconsider the protection and the development planning of their water resources. Officials are faced with making decisions with often far-reaching consequences, requiring sound supporting information and analytical assessments.

Qingdao City in Shandong Province is among the many cities in the northern parts of the People's Republic of China with serious concerns for its water security. Rapid economic growth over the last 3 decades has significantly increased demand for water. Following increasing water abstractions, there has been a sharp decline in the runoff volume of the Dagu River, the largest river in the Jiaodong Peninsula and traditionally known as the mother river of Qingdao City. ${ }^{1}$ Water flow is controlled through a series of upstream dams, and large agricultural development and intensification resulted in increased agricultural water use. Frequent drying up of the river course has occurred, making the available surface water resources in the Dagu River Basin insufficient and unreliable.

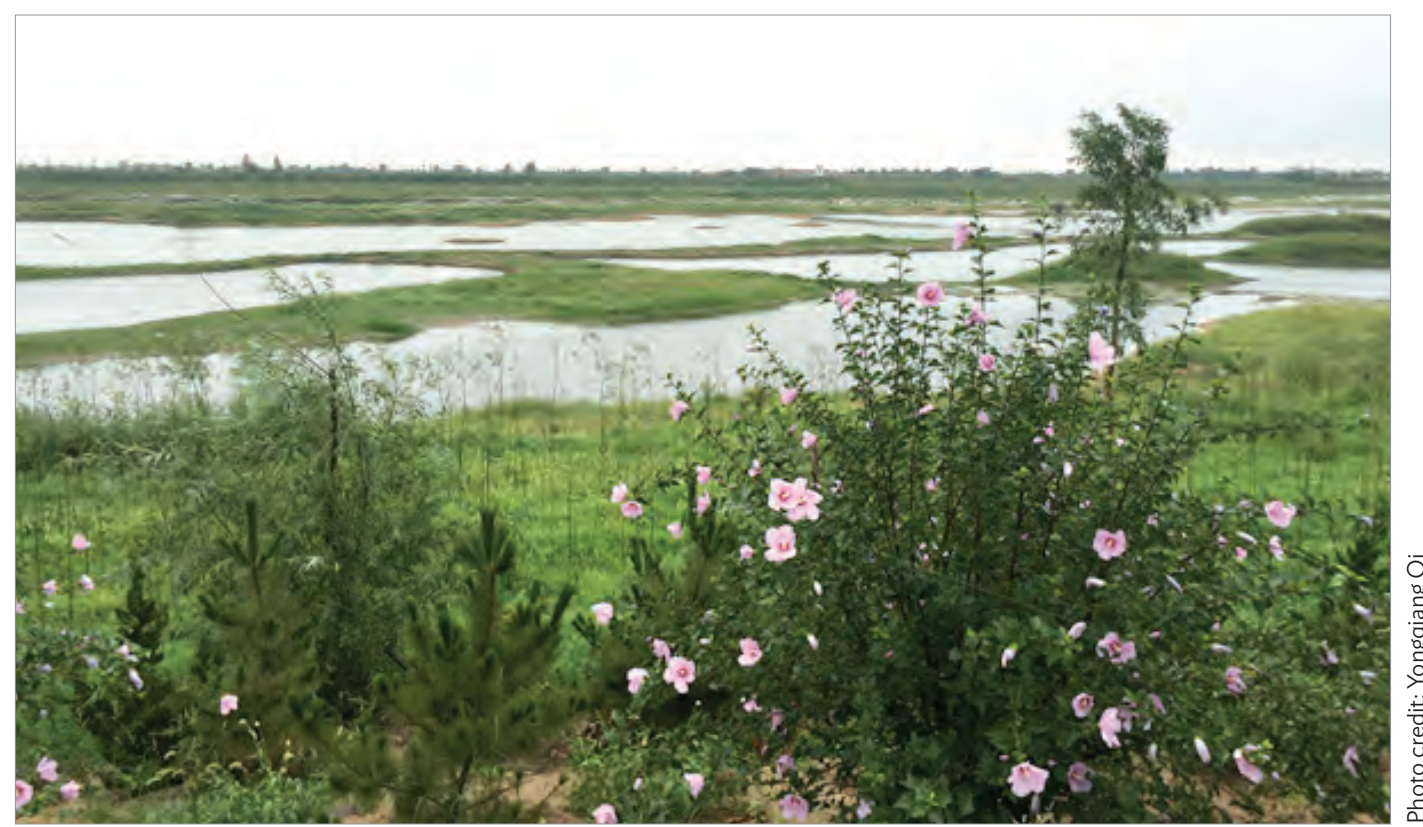

1 The total Dagu watershed is about 4,160 square kilometers. The average annual water flow at the Nuncan hydrological station, located in the middle section of the Dagu aquifer, is estimated to be 526 million cubic meters. 
Since 1981, Qingdao City has been relying on the groundwater resources from the sandy Dagu aquifer in the vicinity of the Dagu River for potable water supply. The Dagu aquifer, with a length of 60 kilometers $(\mathrm{km})$ and an area of 421 square kilometers $\left(\mathrm{km}^{2}\right)$, is located in the lower-middle reaches of the Dagu basin about $50 \mathrm{~km}$ from the urban areas of Qingdao City. The extent of the Dagu aquifer has been the subject of numerous technical studies. ${ }^{2}$ The ancient Dagu River valley plain is made up of fluvial and alluvial unconsolidated quaternary sediments. The sediments consist of sands, silts, and clays deposited by the Dagu River and its tributaries. The sediments constitute a shallow aquifer which overlies basement rocks that outcrop on both sides of the alluvial terraces. The basement rock consists of basalt, clay, and sandstone. The general direction of groundwater flow is from northeast to southwest. A series of cross-sections are presented in Figure 1 covering the upper, middle, and lower reaches of the Dagu aquifer. ${ }^{3}$
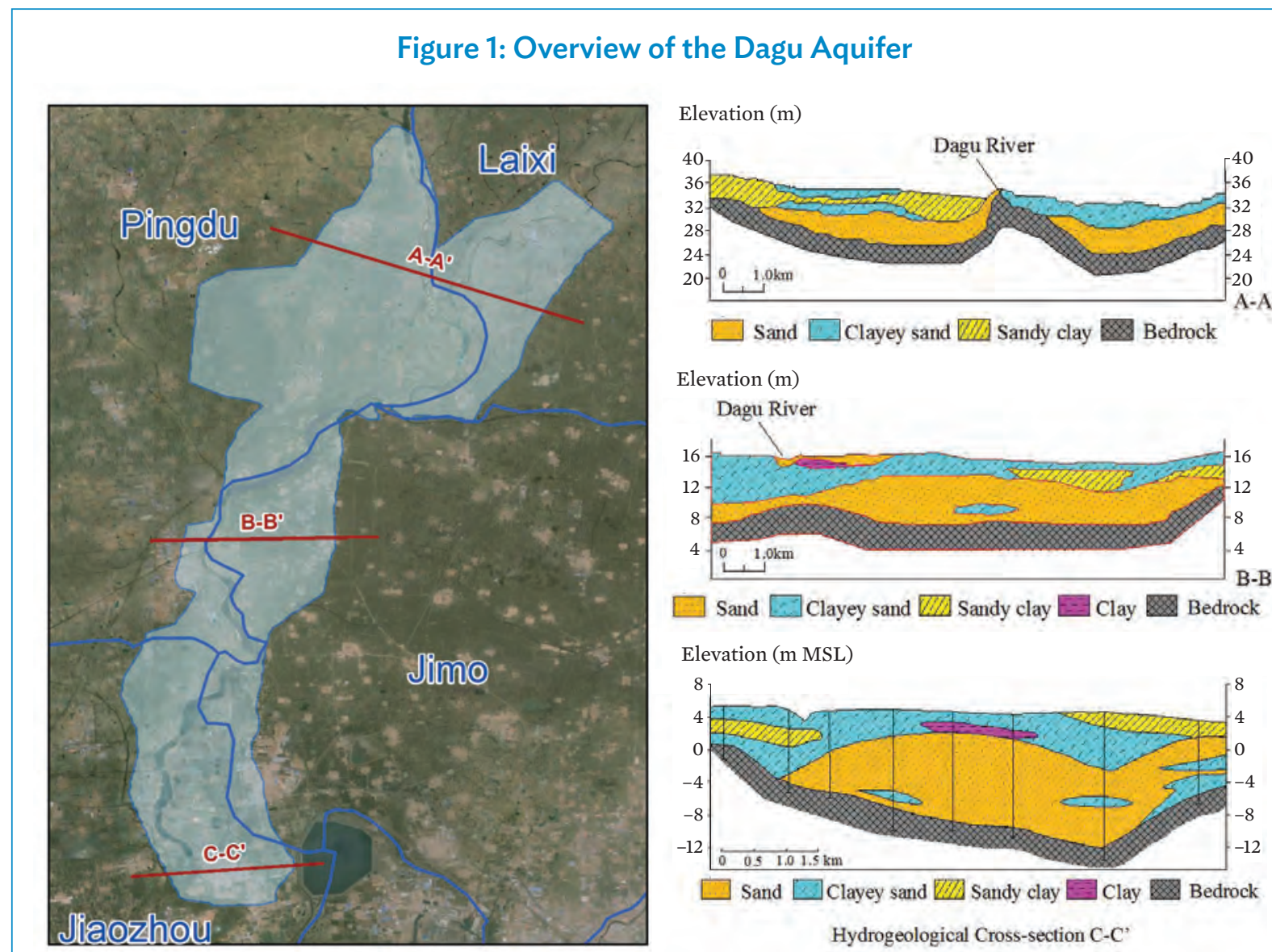

Elevation (m)

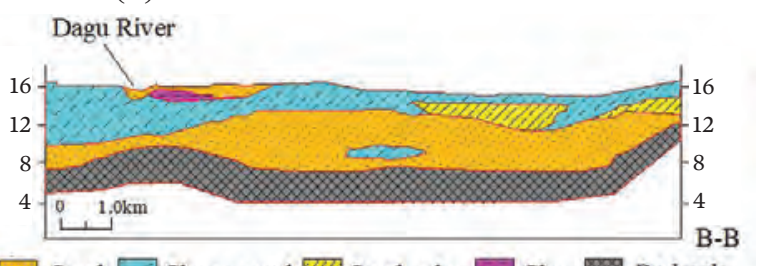

Sand $\square$ Clayey sand $\square$ Sandy clay Bedrock

Elevation (m MSL)

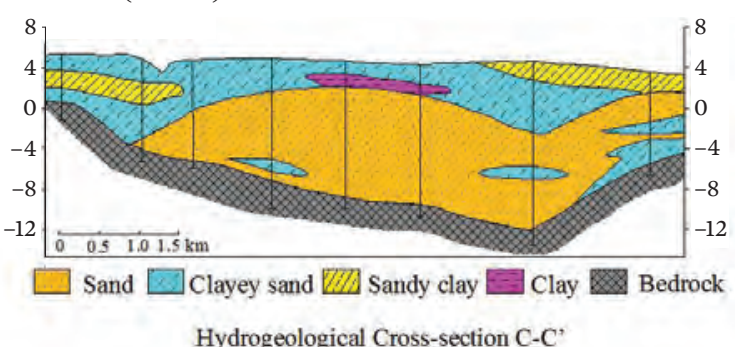

$\mathrm{km}=$ kilometer, $\mathrm{m}=$ meter, $\mathrm{MSL}=$ mean sea level.

Sources: X. Zheng et al. 2006. Sustainable Development and Protection of Costal Groundwater Reservoirs. Beijing. China Geological Press.

ADB. 2015. Dagu Groundwater Rehabilitation and Protection. Manila. Final Report. ADB Technical Assistance TA 47050001. Prepared by Beijing Water International and Ecoseal.

2 E.g. X. Zheng et al. 2006. Sustainable Development and Protection of Costal Groundwater Reservoirs. Beijing. China Geological Press; Y. Chen et al. 2010. Influence of Agricultural Activity and Aquifer Intrinsic Vulnerability on Groundwater Quality in the Dagu River Watershed (Qindao, China). In 2010 4th International Conference on Bioinformatics and Biomedical Engineering. iCBBE 2010. 18-20 June.

3 See Chen et al. (2010) in footnote 2. 
The aquifer consists of alluvial unconsolidated sediments formed by the Dagu River, generally comprising two sand and gravel layers sandwiched between relatively low-permeability silt and a clay layer. ${ }^{4}$ The aquifer is generally $5-20$ meters (m) thick, and at places the total thickness is as much as $30 \mathrm{~m}$. Average thickness of the saturated aquifer is $6 \mathrm{~m}$ and the typical water level fluctuates within a year by no more than $3 \mathrm{~m}$. The thickness of the unsaturated zone varies between locations. In the upper reaches, the unsaturated zone is 3-5 m thick; in the middle reaches, the unsaturated zone is $2-3 \mathrm{~m}$ thick; and in the lower reaches, it exceeds $7 \mathrm{~m}$ in thickness. In one area in the middle reaches of the Dagu River, north of Nancun hydrological station, lays a thin sand unsaturated zone and has been termed an infiltration window. This area of enhanced infiltration covers $9.2 \mathrm{~km}^{2}$ and has a higher vulnerability to groundwater pollution.

The average annual precipitation of the area is 625 millimeters $(\mathrm{mm})$. Among the years with records (1965-2001), the highest precipitation was in 1975 with $953 \mathrm{~mm}$ and the lowest was in 1997 with $317 \mathrm{~mm}$. Much of the rainfall and irrigation recharge occurs from June to September when approximately $70 \%$ of the annual rainfall takes place. Recharge to the Dagu aquifer is principally from precipitation, irrigation recharge, and river leakage, and a small amount from lateral inflows. The area shows a considerable spatial variability in aquifer properties, which has a direct influence on recharge and contamination of the aquifer.

By the mid-1980s, groundwater usage accounted for $80 \%$ of the total water usage of Qingdao City. The dependence on groundwater was partially reduced in 1989 when the Yellow River was diverted to Qingdao as an additional water source. Currently, groundwater in the Dagu aquifer provides about $17 \%$ of the city water supply and is the largest and most stable drinking water source for Qingdao. The aquifer plays an essential role in ensuring the security of potable water of the city and has been listed in the directory of important potable water sources of the People's Republic of China.

The need, however, to protect and use all available water sources due, among others, to growing population, rising urbanization, and intensification of agricultural production has also exerted increasing pressure on the groundwater resources of the Dagu aquifer. ${ }^{5}$ Combined annual groundwater abstraction for agricultural and municipal uses during 1981-1995 was in the 43 million-102 million cubic meter $\left(\mathrm{m}^{3}\right)$ range. ${ }^{6}$ From 1988 to 2008 , the estimated average annual groundwater abstraction was 65 million $\mathrm{m}^{3}$ per year for agricultural and municipal uses. $^{7}$ Over the past 2 decades, the function of this resource has gradually shifted to also supporting agricultural activities in the Dagu basin. Currently, the net agricultural pumping (after subtracting irrigation return flows) accounts for $85 \%$ of the net discharge of the aquifer. ${ }^{8}$ As a result of the increase in agricultural activities, pollution in the Dagu aquifer is increasing, with leaching of nitrogen from agricultural systems a significant source of this pollution, and

4 G. Q. Lin and X. L. Zheng. 2008. Simulation of Recovery Options of Brackish Water Aquifer in the Dagu River Area, China. In 2008 2nd International Conference on Bioinformatics and Biomedical Engineering. iCBBE 2008. 16-18 May. pp. 2966-2969.

5 The population of Qingdao has grown from 6.6 million in 1990 to over 9.0 million in 2014. The urban population in 2014 was around 6 million.

6 X. Zheng et al. 2007. Development and Protection of Coastal Groundwater Reservoir. Beijing: China Geological Press.

7 G. Lin. 2003. Study on the Sustainable Utilization of Water Resource of the Groundwater Storage in Dagu River.

8 C. Y. Jiao, H. X. Qiu, and G. Q. Liu. 1994. A Numerical Model for Dagu Water Source in Qingdao. Journal of Ocean University of Qingdao Vol.24 (supplement), p122-126. (in Chinese). 
the degree of pollution is deteriorating with each year. ${ }^{9}$ The aquifer is also subject to pollution from pesticides. Seven out of nine types of organic phosphate pesticides were detected from samples of 20 sites within the Dagu aquifer. The results showed that only Malathion had values higher than the national standard. ${ }^{10}$

Trends in fertilizer usage. In the Dagu River Basin area, roughly $75 \%$ of land is used for agriculture, with the exception of the cities of Laixi and Jiaozhou. Among the major crops cultivated are wheat, peanuts, corn, vegetables, and fruit trees. The Qingdao Municipal Statistics Bureau reported that, over the last 60 years since 1949, while the total area for agricultural land use decreased, yields from both grain and cash crops increased dramatically as a result of a shift from traditional farming practices to more efficient agricultural production. ${ }^{11}$ Local farmers were encouraged to focus on vegetable cultivation because of its greater yield advantage and its relatively higher prices. Besides these market incentives, the local government also initiated various agricultural technology promotion programs to enhance local vegetable planting. With these agricultural technology programs, intensive planting increased irrigation efficiency, greenhouses with solar heating systems made multiple cropping and harvests possible, and the application of compound fertilizers formulized for the target soil types increased the usage efficiency of fertilizer.

The average estimated fertilizer usage in the Dagu basin rapidly rose from 69 kilograms per hectare (kg/ha) in 1965 to $600-1,000 \mathrm{~kg} / \mathrm{ha}$ in $2012 .{ }^{12}$ Because of the predominantly sandy

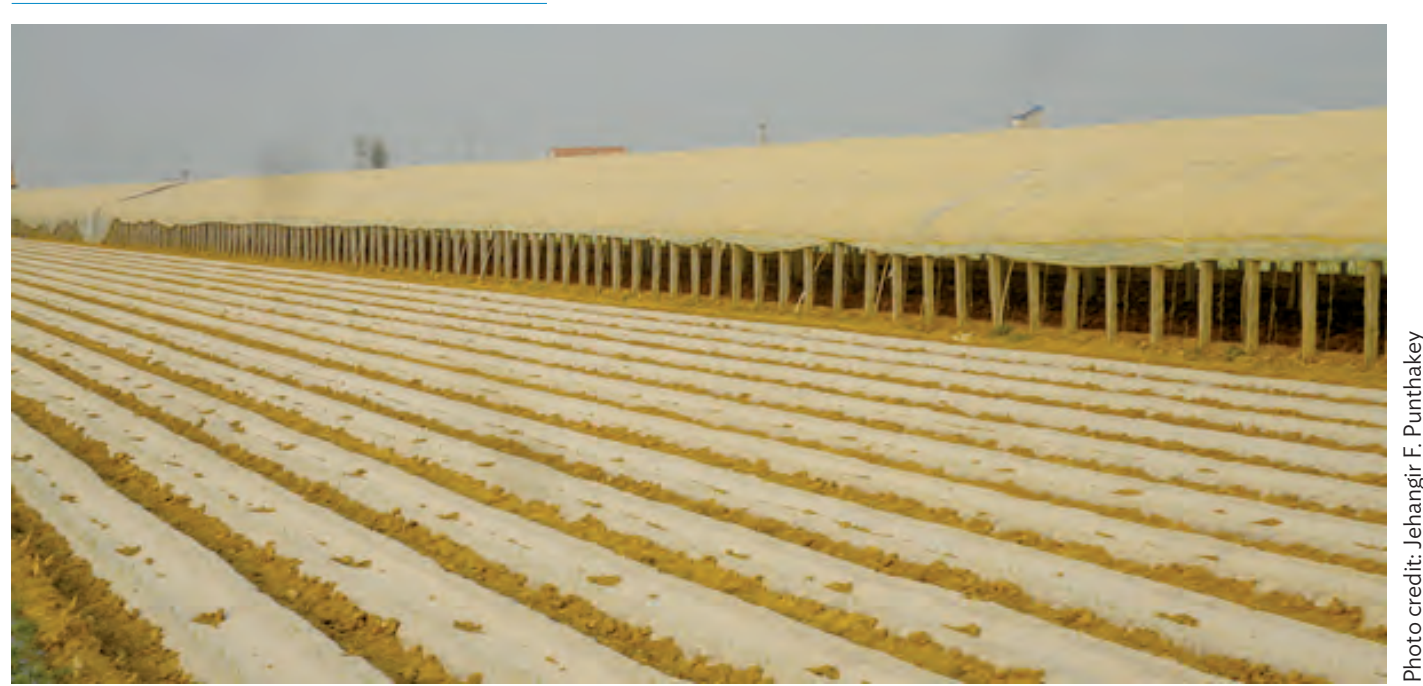

9 Y. J. Ma. 2009. Water Quality Evaluation and Human Health Risk Assessment of Dagu River Groundwater Reservoir. Master's thesis, Ocean University of China.

${ }^{10}$ Malathion is commonly used to control mosquitos and a variety of insects that attack fruits, vegetables, landscaping plants and shrubs. Under most conditions, the half-life appears to be roughly 7-14 days. Malathion has been detected in surface water and drinking-water at concentrations below 2 milligrams/liter. Intake of malathion from all sources is generally low and well below the allowable daily intake. As the chemical occurs in drinking-water at concentrations much lower than the health-based value, the presence of malathion in drinking-water under usual conditions is unlikely to represent a hazard to human health. Source: World Health Organization. www.who.int

11 Qingdao Municipal Statistics Bureau. 2013. Qingdao Statistical Yearbook. Beijing. China Statistics Press.

12 The average fertilizer usage ranged from $600 \mathrm{~kg} / \mathrm{ha}$ to $900 \mathrm{~kg} / \mathrm{ha}$, while fertilizer usage for vegetable planting areas ranged from $500 \mathrm{~kg} / \mathrm{ha}$ to 2,000 kg/ha. Qingdao Municipal Statistics Bureau. 2006. Qingdao Statistical Yearbook. Beijing. China Statistics Press. 
soil in the Dagu aquifer, the fertilizer residues in the soil are easily transported from the soil to the aquifer along with precipitation and irrigated water. Excessive amounts of fertilizer are retained in the soil until the next irrigation or rainfall event. This is the common cause of nitrate contamination, especially in a shallow sandy aquifer like the Dagu aquifer (Figure 2).

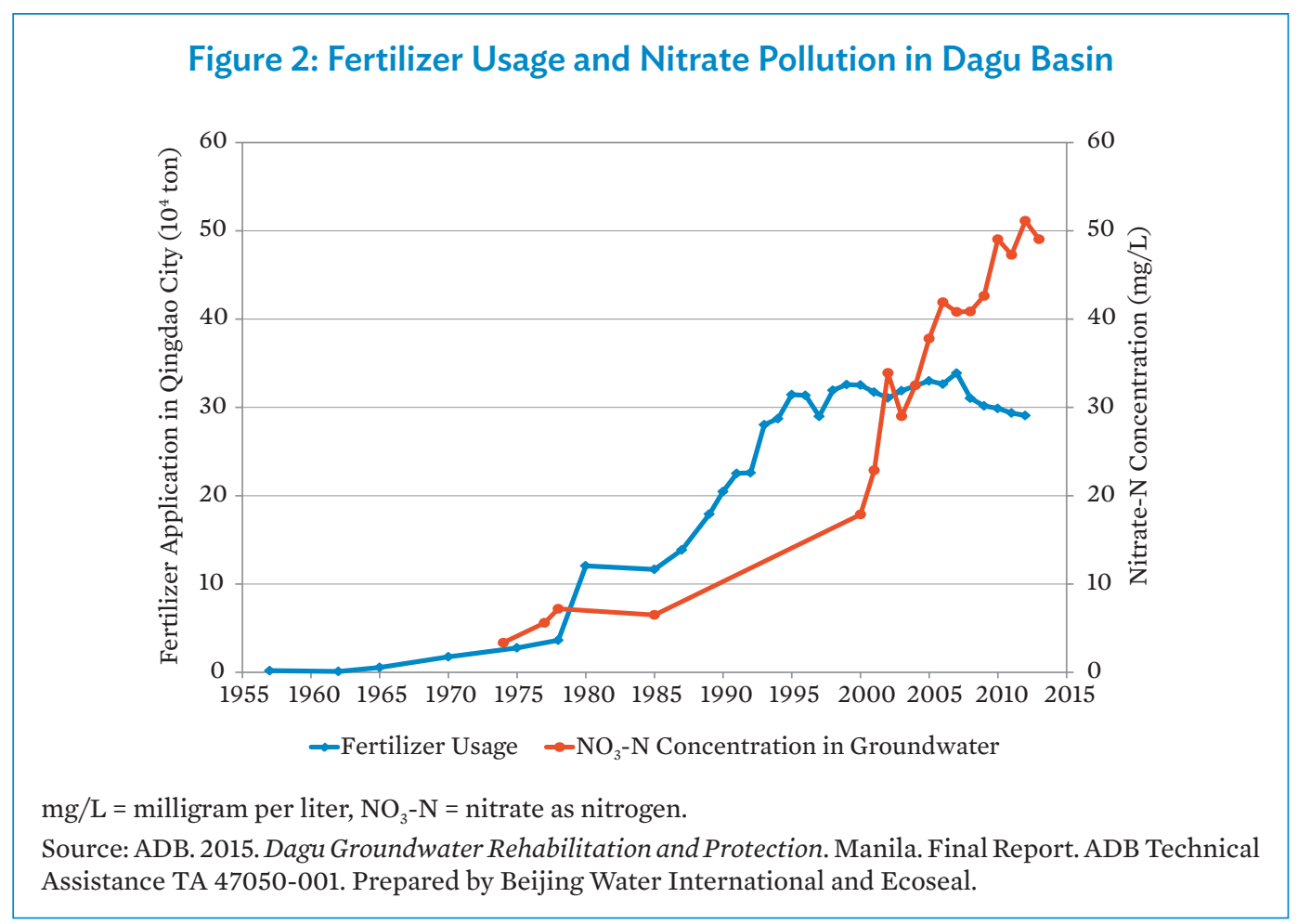

The Qingdao Municipal Government attaches great importance to the sustainable development and utilization of the Dagu groundwater resources. In recent years, significant resources have been mobilized to conduct surveys and research in the area, such as hydrology, geology, hydrogeology, water quality, and environment capacity. Extensive and accurate data such as quantity of groundwater and environmental pollution situation have been made available. The government also invested significantly in riverbank reinforcement, construction of underground reservoirs, rubber dams, and other engineering measures to effectively optimize groundwater exploitation. 


\section{Informed Decision Making: Facts versus Fiction}

T ack of consensus. Despite the significant efforts, there remained a lack of consensus 1 among the many stakeholders on the most effective way to protect and exploit the Dagu groundwater resources in a more sustainable way. To get a better understanding, and reach a consensus among the key stakeholders, the Qingdao Municipal Government requested support from the Asian Development Bank to prepare a comprehensive Dagu groundwater rehabilitation and protection plan for Qingdao City and ensure a more sustainable implementation of groundwater management in the Dagu river basin. ${ }^{13}$ In particular, there was a strong interest to get a common view on the possible sustainable yield of the aquifer and clarity on the options to reduce pollution from the agriculture sector. Four key activities were identified to attain the expected outcome: (i) a comprehensive assessment of the Dagu groundwater resources, (ii) the establishment of a groundwater resources information management system, (iii) an assessment of groundwater pollution treatment options, and (iv) the preparation of a Dagu groundwater resources management plan.

In the course of the technical assistance project, a comprehensive assessment of the water resources conditions in the Dagu area was conducted, covering extensive data sources from various agencies such as the Qingdao Hydrological Bureau, the Department of Water

How Much Water and Fertilizer Can Be Used in a Sustainable Way?

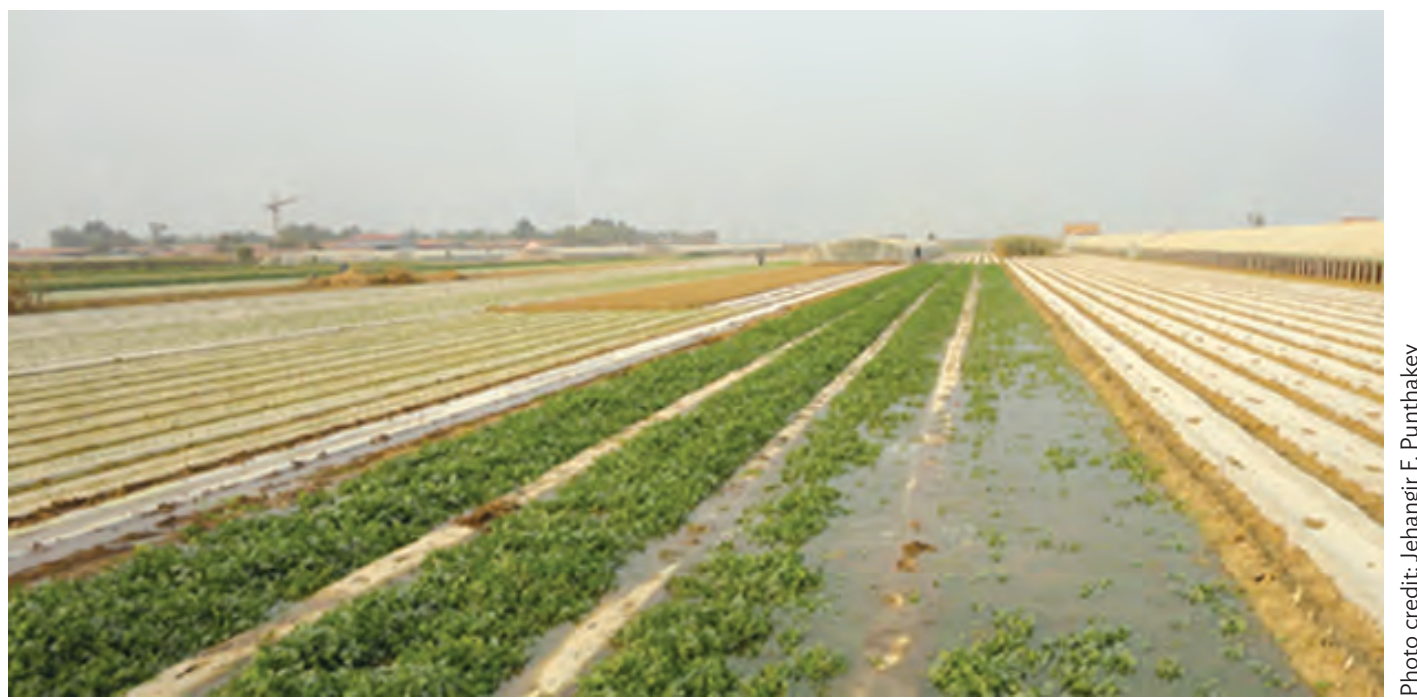

13 The technical assistance budget was $\$ 400,000$, of which $\$ 300,000$ was financed by the Asian Development Bank from its Technical Assistance Special Fund (TASF) and \$100,000 was financed by the Qingdao Municipal Government. The project was implemented with the support from Beijing Water International and Ecoseal Developments. 
Resources, the Department of Land Resources, and the Department of Environmental Protection. A comprehensive database and information system was developed and used for the preparation of the groundwater management plan (Figure 3).

\section{Figure 3: Fence Diagrams with Related Base Map in the Dagu Database}

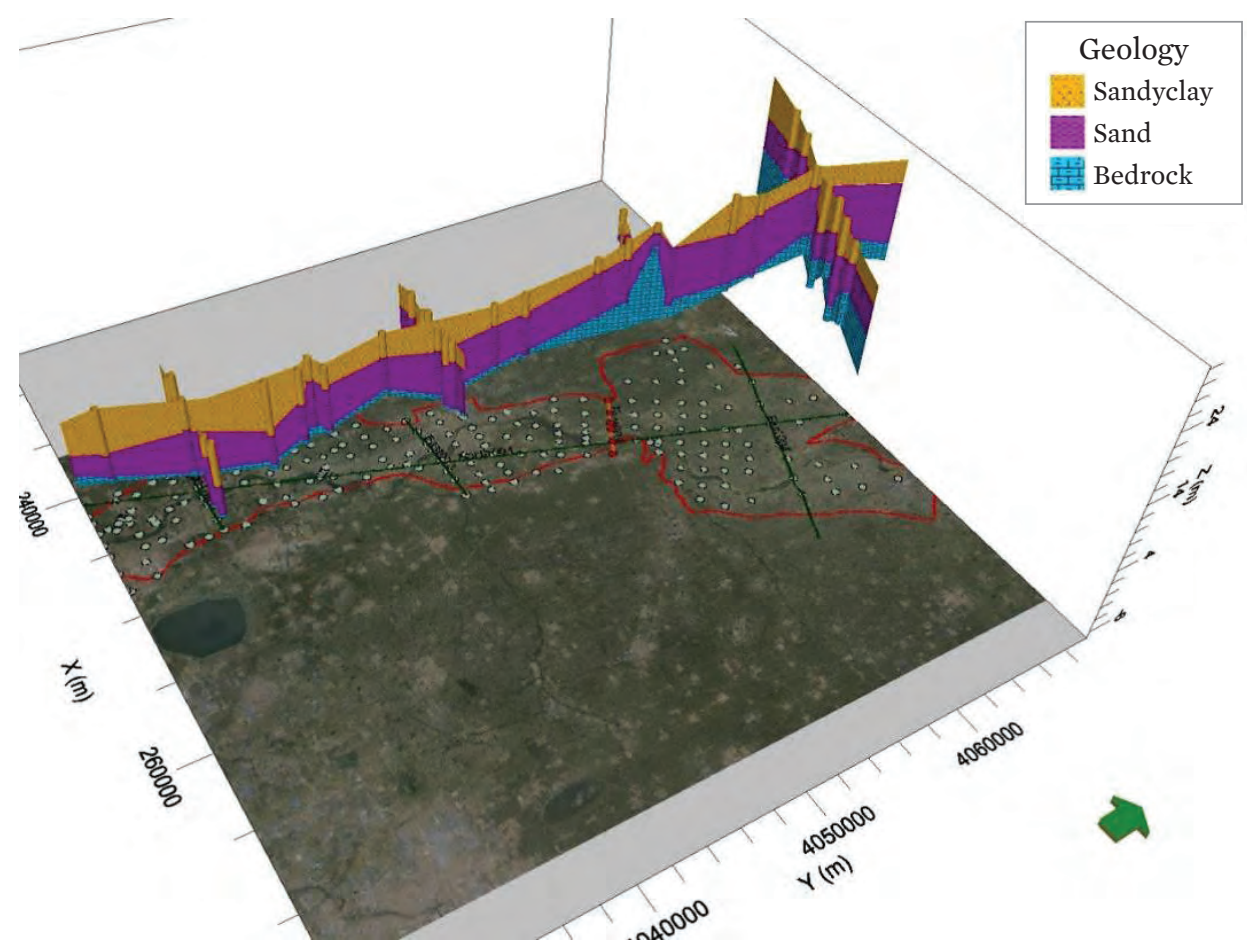

$\mathrm{m}=$ meter.

Note: The dots on the map are the locations of available boreholes. They used to be a channel network collecting groundwater pumped from these wells for the city.

Source: ADB. 2015. Dagu Groundwater Rehabilitation and Protection. Manila. Final Report. ADB Technical Assistance TA 47050-001. Prepared by Beijing Water International and Ecoseal.

The system, which has been handed over to the Qingdao Hydrological Bureau, formed the basis for the numerical modeling of groundwater levels and abstraction scenarios, considering possible changes in climate change and precipitation. A comprehensive assessment of the pollution threats and treatment options, including in situ treatment, pumping and treatment, and pumping and fertilization, was carried out. Cost implications have been calculated, and promising alternatives such as the use of slow-release fertilizers and pumping and fertilization were prepared. With the support of the numerical groundwater model, the effectiveness of engineering structures in the Dagu aquifer was assessed. 


\section{Sustainable Yields: Key to Water Resources Planning}

TT Tater balance basics. Through the elaborate mathematical modeling exercise, the various stakeholders were able to reach a consensus on the basic magnitude of the water balance of the Dagu aquifer. ${ }^{14}$ The model enabled the Qingdao Municipal Government to present an in-depth overview of the average annual water balance of the Dagu aquifer for the period January 2009-August 2014 (Table). The review also indicated that the volume of groundwater storage in the aquifer is estimated at around 200 million $\mathrm{m}^{3}$.

\section{Table: Average Annual Water Balance of the Dagu Aquifer,} January 2009-August 2014

\begin{tabular}{|c|c|c|c|c|c|}
\hline \multicolumn{3}{|c|}{ RECHARGE (IN) } & \multicolumn{3}{|c|}{ EXTRACTION (OUT) } \\
\hline Component & $\begin{array}{c}\text { Volume } \\
\left(\text { million } \mathrm{m}^{3}\right)\end{array}$ & $\begin{array}{l}\text { Percent } \\
(\%)\end{array}$ & Component & $\begin{array}{c}\text { Volume } \\
\left(\mathrm{million}^{3} \mathrm{~m}^{3}\right)\end{array}$ & $\begin{array}{l}\text { Percent } \\
(\%)\end{array}$ \\
\hline Rain infiltration & 59 & 57.8 & Agricultural pumping & 75 & 72.3 \\
\hline Irrigation return & 20 & 20.0 & Municipal pumping & 7 & 6.4 \\
\hline River infiltration & 13 & 13.1 & River discharge & 17 & 16.7 \\
\hline \multirow[t]{2}{*}{ Lateral recharge } & 9 & 9.1 & Lateral discharge & 2 & 2.2 \\
\hline & & & Evapotranspiration & 13 & 2.4 \\
\hline Total & 102 & 100.0 & Total & 104 & 100.0 \\
\hline
\end{tabular}

$\mathrm{m}^{3}=$ cubic meter.

Note: Storage change during the calculation period was -2 million $\mathrm{m}^{3}$.

Source: ADB. 2015. Dagu Groundwater Rehabilitation and Protection. Manila. Final Report. ADB Technical Assistance TA 47050-001. Prepared by Beijing Water International and Ecoseal.

The modeling showed that the current groundwater extraction rates are likely to be sustainable as long as the annual yield of around 62 million $\mathrm{m}^{3}$ is safely maintained (Figure 4$) .{ }^{15}$ As the exploitation of the Dagu aquifer is dominated by agricultural usage, the groundwater available for pumping may even go up to 82 million $\mathrm{m}^{3}$ per year, assuming an irrigation return rate of $20 \%{ }^{16}$

The modeling exercise also demonstrated, however, that any significant increase in pumping beyond current sustainable levels will result in critical reductions in aquifer storage (Figures 5 and 6). ${ }^{17}$ Moreover, the aquifer will be water stressed during successive drought years when demand for groundwater increases in response to below-average rainfall conditions. This

14 The transient model calibration period was from January 2009 to August 2014.

15 The yield of 62 million $\mathrm{m}^{3}$ is the total pumping $\left(75\right.$ million +7 million $\left.\mathrm{m}^{3}\right)$, minus irrigation return $\left(20\right.$ million $\left.\mathrm{m}^{3}\right)$.

${ }^{16}$ Rigorous testing was performed to validate the various key assumptions.

17 The aquifer volume is calculated based on the surface of bedrock and each day's water table. It is noted that land subsidence is not considered a critical concern as the area comprises a shallow mostly unconfined aquifer. 
Figure 4: Model Calibration with Historic Groundwater Levels, December 2008-December 2013

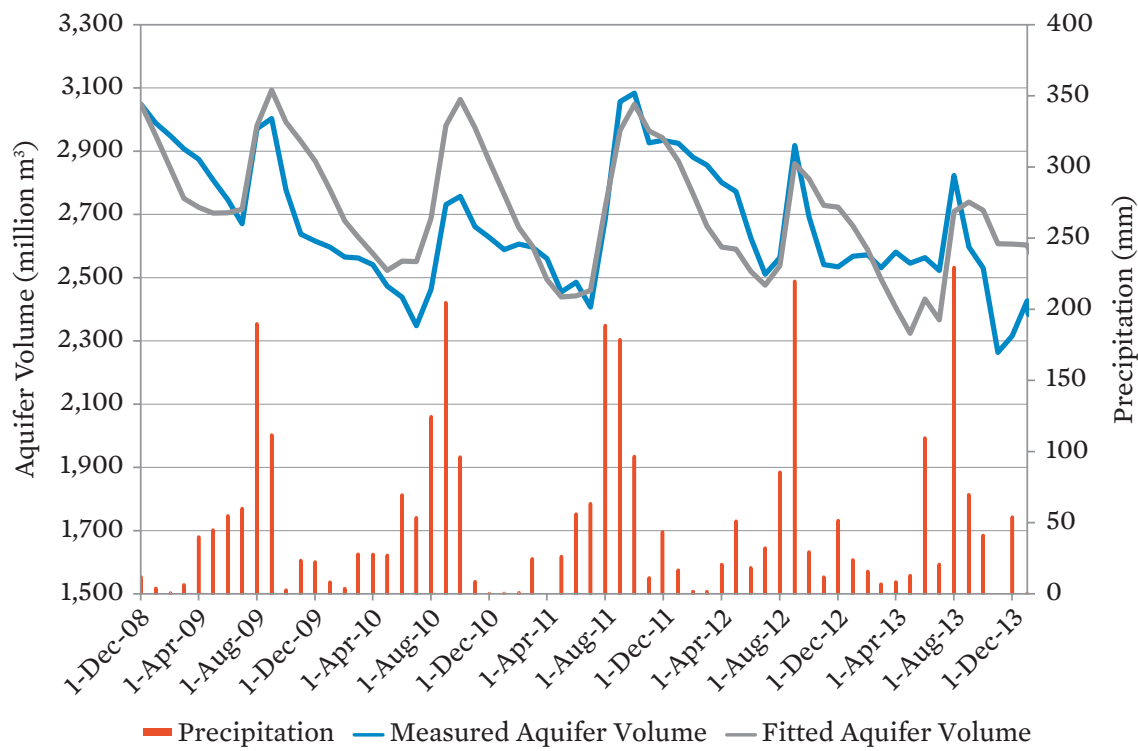

$\mathrm{m}^{3}=$ cubic meter, $\mathrm{mm}=$ millimeter.

Source: ADB. 2015. Dagu Groundwater Rehabilitation and Protection. Manila. Final Report. ADB Technical Assistance TA 47050-001. Prepared by Beijing Water International and Ecoseal.

Figure 5: Model Calibration with Historic Groundwater Levels, January 2014-August 2014

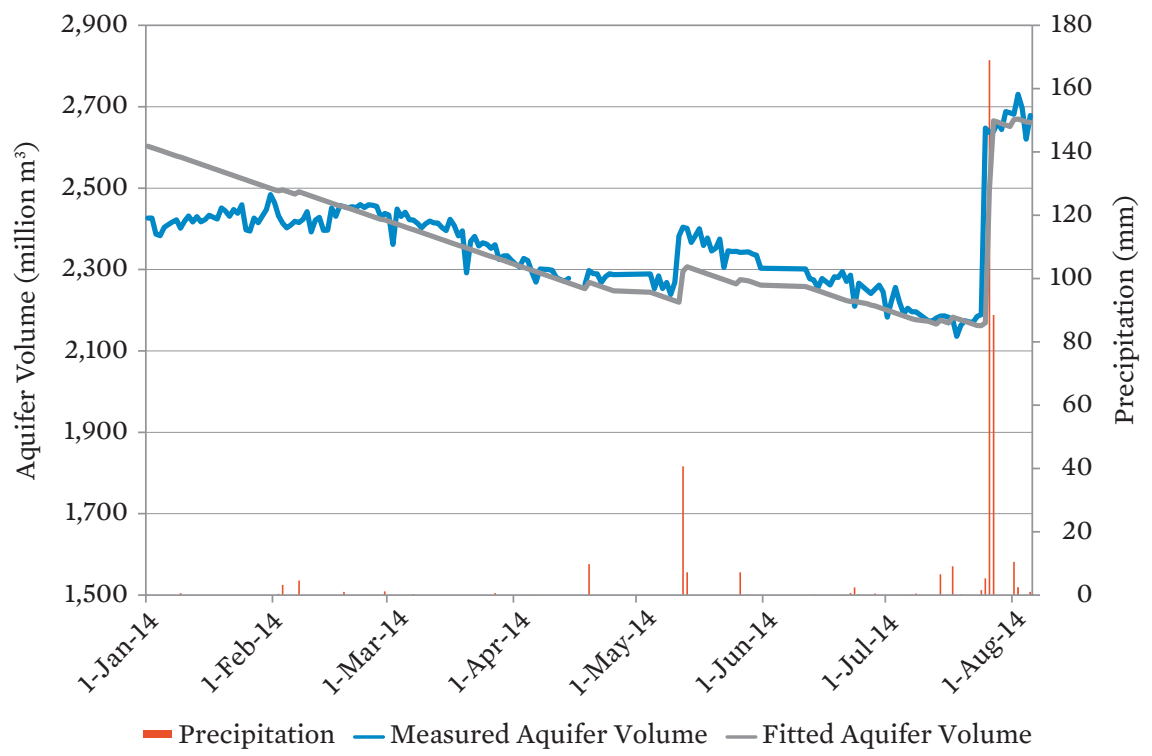

$\mathrm{m}^{3}=$ cubic meter, $\mathrm{mm}=$ millimeter

Source: ADB. 2015. Dagu Groundwater Rehabilitation and Protection. Manila. Final Report. ADB Technical Assistance TA 47050-001. Prepared by Beijing Water International and Ecoseal. 
Figure 6: Modeling Impacts of Different Pumping Scenarios

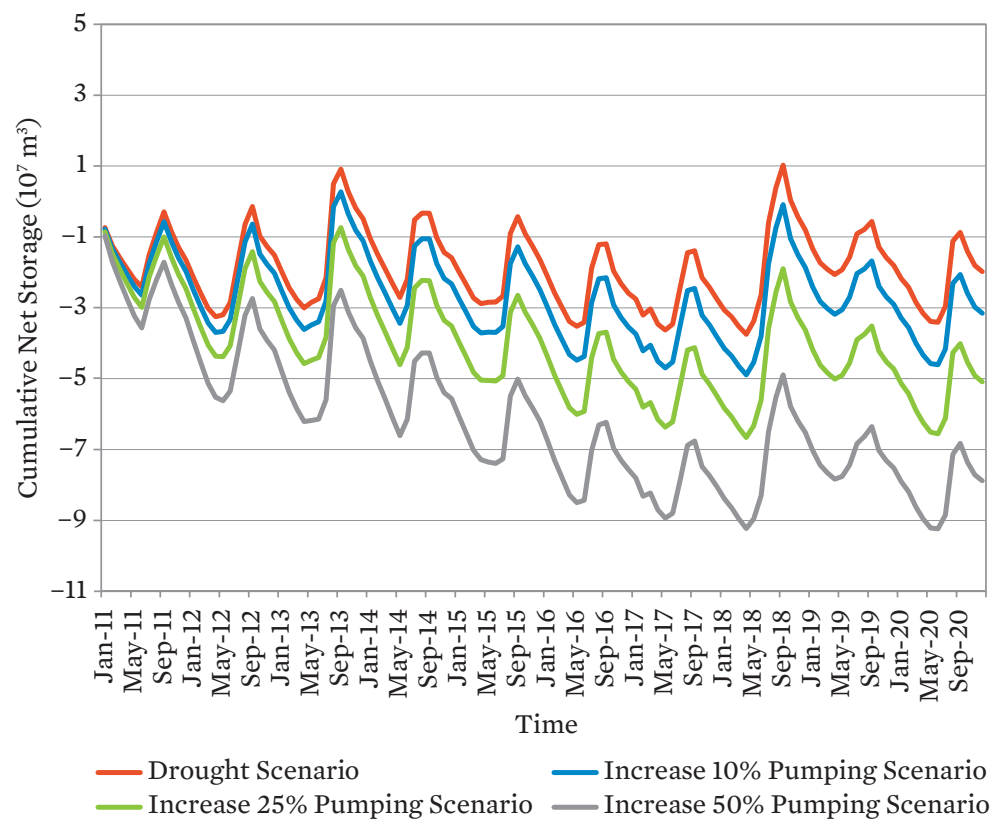

$\mathrm{m}^{3}=$ cubic meter.

Source: ADB. 2015. Dagu Groundwater Rehabilitation and Protection. Manila. Final Report. ADB Technical Assistance TA 47050-001. Prepared by Beijing Water International and Ecoseal.

would also result in steep declines in the aquifer's water levels and increased concentration of nitrates. The modeling exercise also indicated that recovery of the aquifer can be quick, assuming sufficient recharge.

Acknowledging the increasing importance of climate change, and the need to adapt to climate change impacts, fluctuations of groundwater levels for different climate scenarios were assessed (Figure 7). The analysis shows that droughts have important adverse effects on the changes in groundwater resources. Critical reductions in aquifer storage occur over longer period of times as a result of insufficient recharge.

Finally, considering the need to maintain the economic production and maximize the usage of productive agricultural lands, greater focus should be placed on improving irrigation by introducing drip irrigation, particularly for high-value vegetable crops, in combination with reduced fertilizer usage. Ensuring a focus on improving agricultural water productivity should remain a key focus by the Qingdao Municipal Government. Moreover, to be able to capitalize on storing water in the aquifer when water is abundant, such as during the monsoon season or when there is above-average rainfall, increased efforts should be considered to introduce water-savings technologies such as managed aquifer recharge and water banking. 
Figure 7: Modeling Impacts of Different Climatic Scenarios

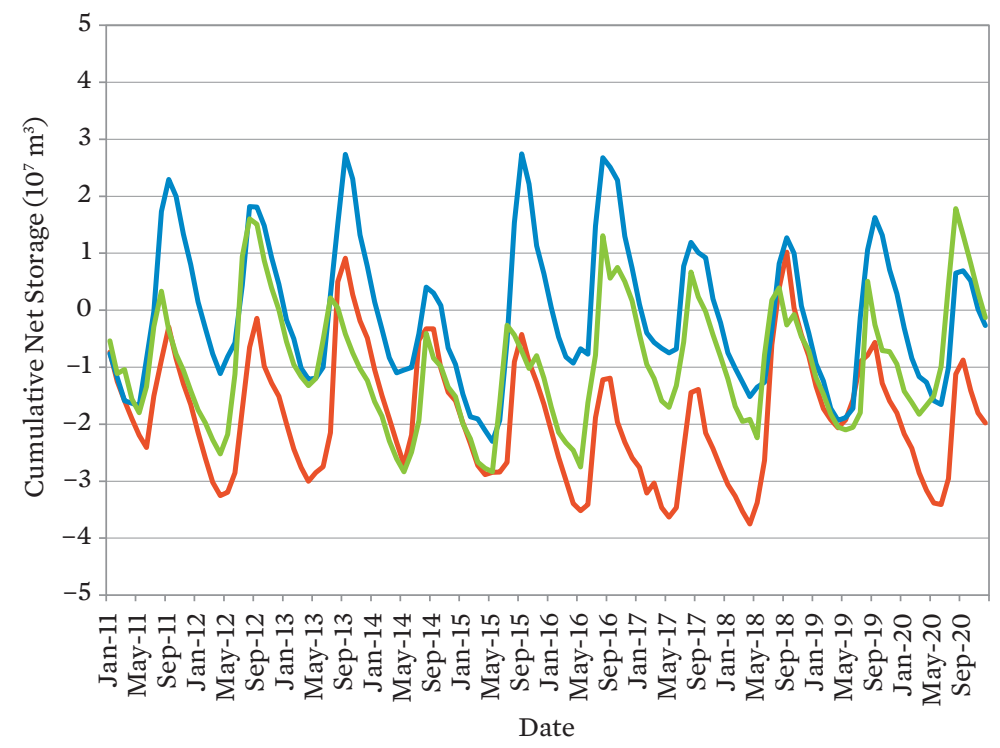

—Drought Scenario — High Rainfall Scenario — Average Scenario

$\mathrm{m}^{3}=$ cubic meter.

Source: ADB. 2015. Dagu Groundwater Rehabilitation and Protection. Manila. Final Report. ADB Technical Assistance TA 47050-001. Prepared by Beijing Water International and Ecoseal. 


\section{Water Quality Concerns: Nonpoint Source Pollution Threats}

$\checkmark$ roundwater contamination. Another important step toward the sustainable

T management of the Dagu groundwater resources was the assessment and understanding of the movement of fertilizers (and their derivatives) through soil into groundwater and surface water systems (Figure 8). Agriculture has been identified as the main source of contamination for the Dagu aquifer. Fertilizer application on the sandy agricultural soils of the Dagu river basin has resulted in the subsequent increase in nutrient concentrations in the groundwater. Based on groundwater sampling conducted in April 2007 (footnote 9), the prevalent concerns are (i) nitrate, for which $65 \%$ of the samples exceeded the national drinking water standard of 20 milligrams per liter (mg/l); (ii) hardness, for which $70 \%$ of samples exceeded the standard of $450 \mathrm{mg} / \mathrm{l}$; and (iii) total dissolved solids, for which $61 \%$ of samples exceeded the standard of $1,000 \mathrm{mg} / 1 .{ }^{18}$ There are indications that some blending of groundwater and surface water has been applied to meet some of the drinking water quality standards.

Among these concerns, nitrate represents the biggest environmental health problem as its spatial average value $(42 \mathrm{mg} / \mathrm{l}$ in nitrate- $\mathrm{N})$ is significantly higher than the national drinking

Figure 8: Schematic Movement of Fertilizers through Soil into Groundwater and Surface Water Systems

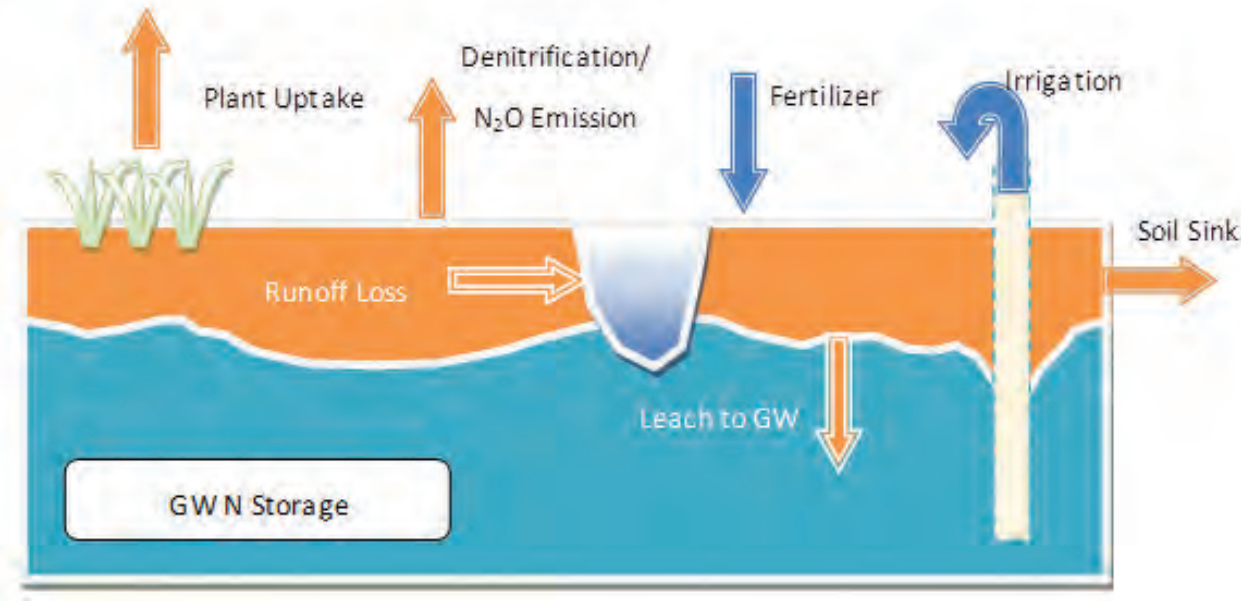

$\mathrm{GW}=$ groundwater, $\mathrm{N}_{2} \mathrm{O}=$ nitrous oxide.

Source: ADB. 2015. Dagu Groundwater Rehabilitation and Protection. Manila. Final Report. ADB Technical Assistance TA 47050-001. Prepared by Beijing Water International and Ecoseal.

18 J. Yujie Ma. 2009. Improvement and Application of Fuzzy Synthetic Evaluation of Groundwater Quality. Journal of China University of Mining \& Technology. 2009-05. 
water standard of $20 \mathrm{mg} / \mathrm{l}$ (in nitrate-N).$^{19}$ Other compounds associated with nitrate are nitrite and ammonia: the former is a carcinogen and the latter an important driver of eutrophication in surface water. In the Dagu aquifer, the nitrite and ammonia concentrations exceed drinking water standards less frequently than for nitrate-of the wells tested, $13 \%$ for ammonia and $4 \%$ for nitrite were reported to exceed drinking water standards. Phosphate has not been tested for groundwater. However, there are surface water monitoring data, collected in spring and fall from 2008 to 2013, indicating that the average concentration of total phosphate in Dagu River was below $0.1 \mathrm{mg} / \mathrm{l}$.

As the primary contaminant in the Dagu aquifer, high nitrate concentrations are found in the upper and middle parts of the aquifer. An assessment of 230 groundwater samples and 200 river samples in 2006 shows that the average nitrate- $\mathrm{N}$ concentration in vegetable planting zones reached $59.9 \mathrm{mg} / \mathrm{l}$ in corn planting zones and $25.1 \mathrm{mg} / \mathrm{l}$ in wheat planting zones. ${ }^{20}$ The lowest nitrate- $\mathrm{N}$ concentrations (below $40 \mathrm{mg} / \mathrm{l}$ ) were observed in the boundary areas of the aquifer where wheat, peanuts, and corn are planted. The assessment further concluded that (i) an abundance of nitrogenous fertilizer is used in the vegetable planting zones, where the utilization ratio is only $30 \%-35 \%$; (ii) nitrogenous fertilizer produces nonpoint source nitrate pollution; and (iii) irrigation water frequency in the vegetable planting zone is five times higher than in corn and wheat planting zones. The volume of irrigation water used in

\section{Agricultural Production-Growing Tomatoes in Greenhouses}

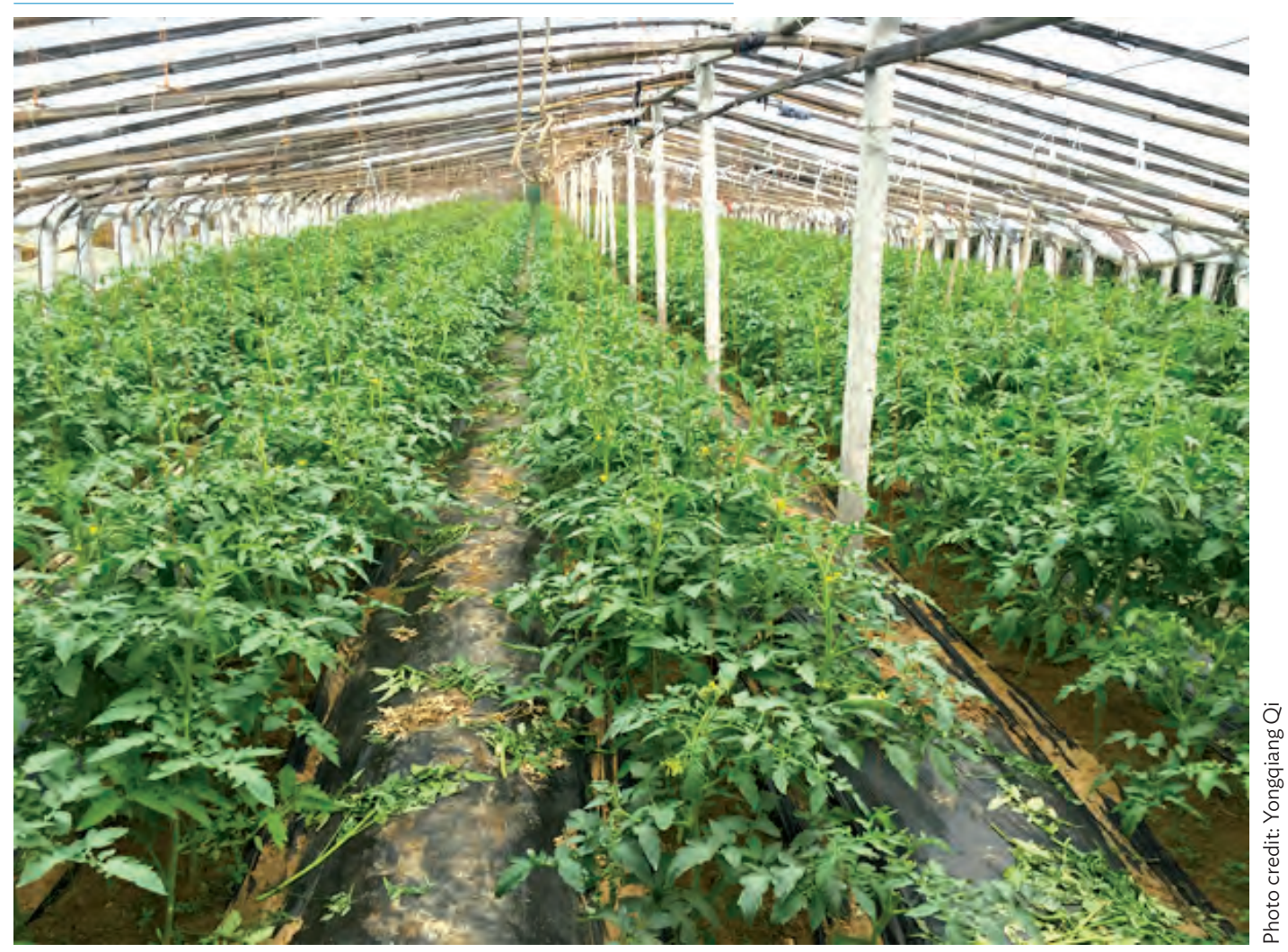

\footnotetext{
${ }^{19}$ Nitrate concentrations discussed in this paper are expressed as nitrate-nitrogen or $\mathrm{NO}_{3}-\mathrm{N}$, not $\mathrm{NO}_{3}$.

${ }^{20}$ G. Q. Liu et al. 2007. Groundwater and Nutrient Discharge into Jiaozhou Bay, North China. Water, Air \& Soil Pollution: Focus. 7 (6). pp. 593-605. doi:10.1007/s11267-007-9127-9; Chen et al. (2010) in footnote 2.
} 
the vegetable planting zones is $7-10$ times as much as in the corn and wheat planting zones. At the same time, lithology of the unsaturated zone also impacts the nitrate- $\mathrm{N}$ concentration in groundwater. Because fine sand has a high infiltration capability, the nitrate penetrated more easily into the fine sand than in clay or silt in the unsaturated zone.

Nitrate hot spots. Four main nitrate pollution "hot spots" were identified through the analyses of 490 samples in 35 sites over the course of 7 years (Figure 9). ${ }^{21}$ An estimated $72.5 \%$ of the 490 samples exceeded the nitrate national drinking water standard. The most contaminated sites

Figure 9: Nitrate Hot Spots in the Dagu Aquifer (Based on Monitoring Data for 2007-2013)

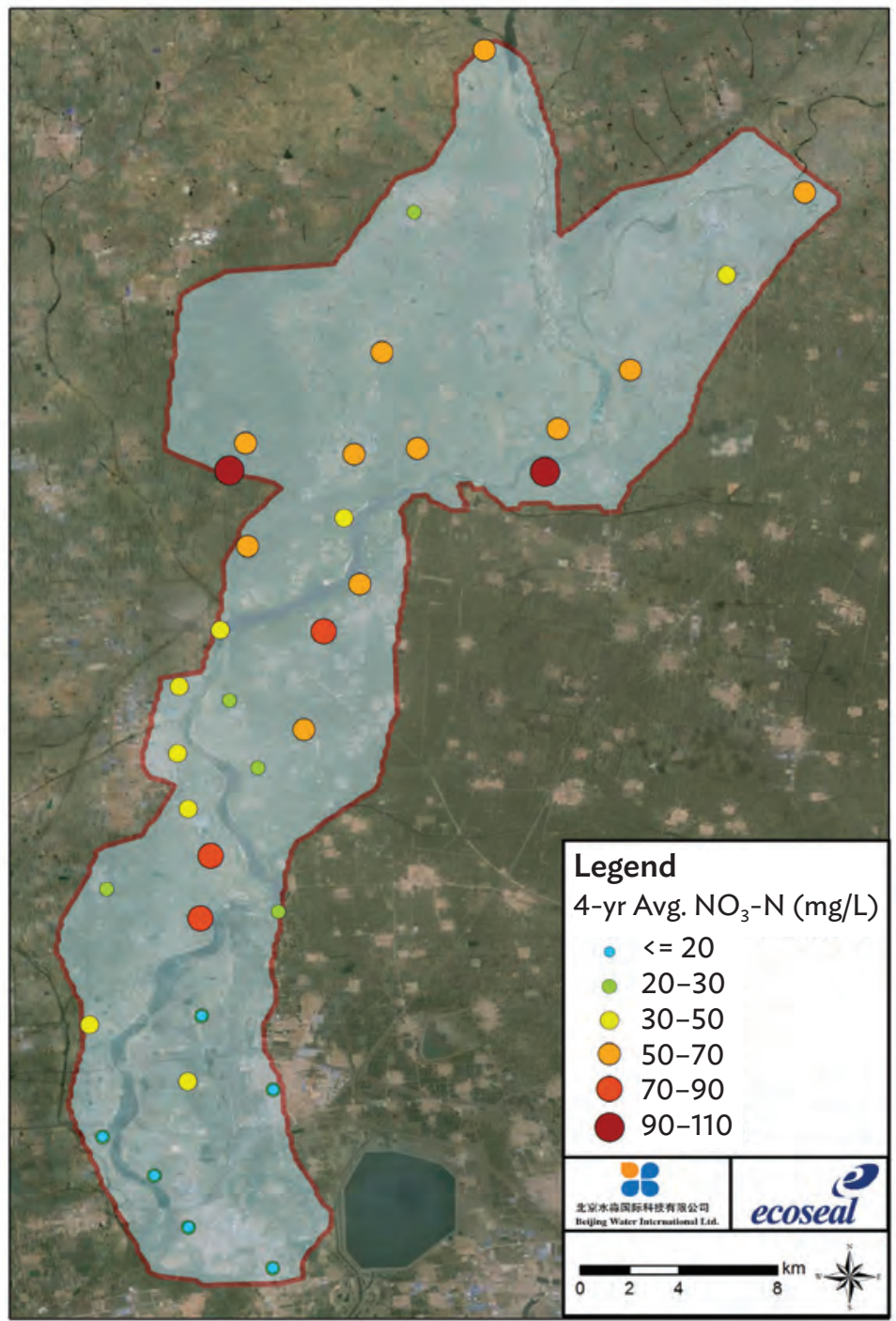

$\mathrm{km}=$ kilometer, $\mathrm{mg} / \mathrm{L}=$ milligram per liter, $\mathrm{NO}_{3}-\mathrm{N}=$ nitrate as nitrogen, $\mathrm{yr}=$ year.

Source: ADB. 2015. Dagu Groundwater Rehabilitation and Protection. Manila. Final Report. ADB Technical Assistance TA 47050-001. Prepared by Beijing Water International and Ecoseal.

${ }^{21}$ Data were collected from the routine groundwater quality monitoring program (2007-2013). 
included the areas surrounding Hanjiahui, Dawangtuan, Lengjiazhuang, and Sanwanzhuang. The nitrate concentrations are consistently higher in areas where the nitrate hot spots occur, as compared with other sites, and they show an increasing trend. Between 2007 and 2013, the groundwater quality at the hot spots deteriorated, while other areas in the Dagu aquifer have had stable nitrate concentrations. Two of the four hot spots are located on the alluvial flat area. The high concentrations there are assumed to be caused by the greenhouse vegetable growing centers. The other two hot spots are located near the edge of the aquifer bedrock boundary. The high nitrate concentrations there are consistent with the shallow overburden and poor circulation condition for groundwater. 


\section{Nonpoint Source Pollution Control: Integrated Solutions}

nd-of-pipe engineering solutions. The technical assistance project reviewed possible engineering technologies for nitrate removal in groundwater. Ex situ biodenitrification (pump-and-treat) is the most well developed and widely implemented method routinely used globally at varying scales. Due to the high solubility and low partitioning of nitrate into soil, pump-and-treat is effective in the removal and concentration reduction of nitrate in all zones of groundwater contamination. Other innovative in situ technologies have also been tested and implemented to treat nitrate in groundwater, particularly the in situ injection of carbon source and the permeable reactive barrier technology.

Considering the literature and the local hydrogeological conditions of the Dagu aquifer, the effectiveness of such end-of-pipe solutions may offer some limited opportunities to speed up the process of dissolving the nitrate hot spots, particularly in the shallower parts of the aquifer. However, they are unlikely to be able to address the overall aquifer contamination concerns, as a first priority remains to reduce the source of the nitrate contamination. Also, pumping may be impractical as it will have to cover large areas (Figure 10). For example, the

Figure 10: Estimated Volume and Location of Groundwater to Be Remediated
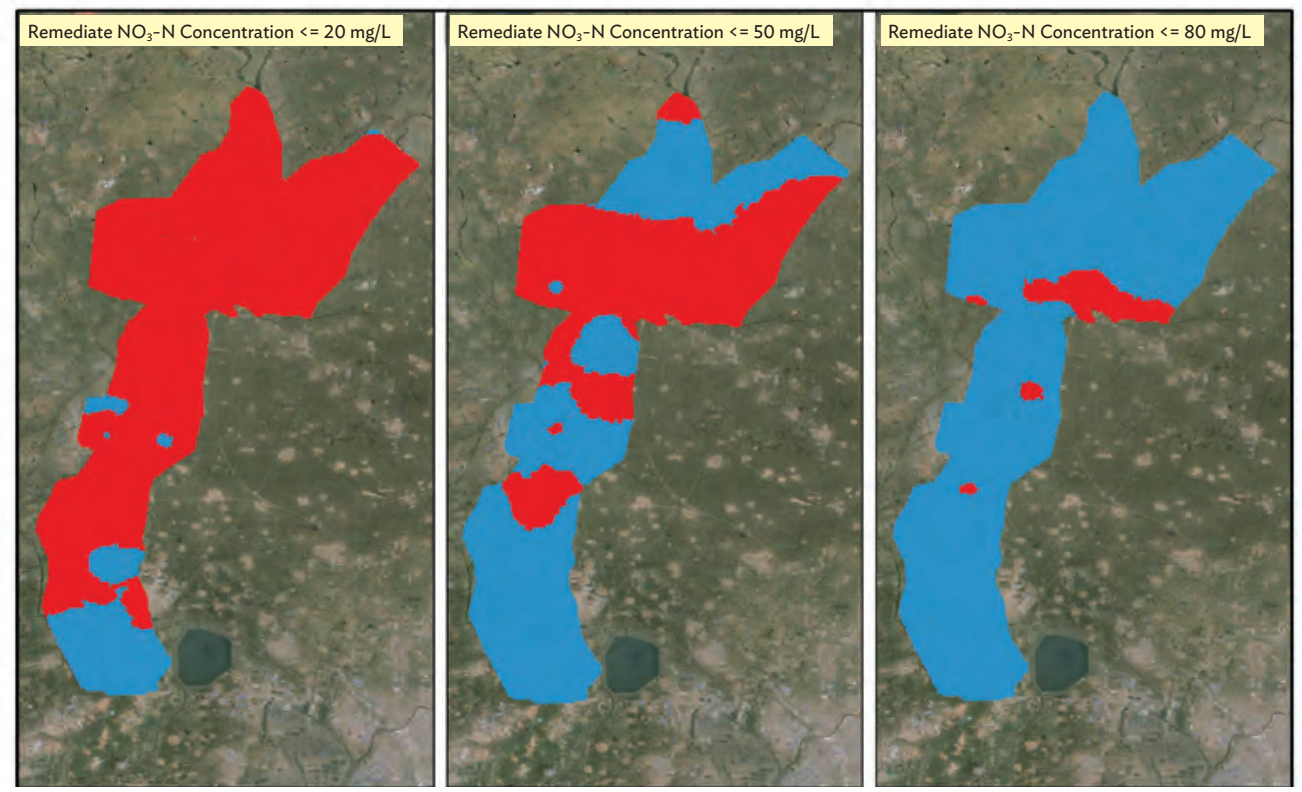

$\mathrm{mg} / \mathrm{L}=$ milligram per liter, $\mathrm{NO}_{3}-\mathrm{N}=$ nitrate as nitrogen .

Note: The estimate volume and location of groundwater which needs to be remediated is shown in red.

Source: ADB. 2015. Dagu Groundwater Rehabilitation and Protection. Manila. Final Report. ADB Technical Assistance TA 47050-001. Prepared by Beijing Water International and Ecoseal. 
estimated water volume in need of remediation is 173 million $\mathrm{m}^{3}, 92$ million $\mathrm{m}^{3}$, and 13 million $\mathrm{m}^{3}$, respectively, if the remediation target for nitrates is set to $20 \mathrm{mg} / 1$ (national drinking water standard), $50 \mathrm{mg} / \mathrm{l}$, and $80 \mathrm{mg} / 1$.

An alternative nutrient management option worth considering would be the pump-andfertilize method. Pump-and-fertilize groundwater remediation requires accounting for any nitrate already present in irrigation water when formulating fertilizer requirements. This approach is a more economical compared with the capital-intensive pump-and-treat system. Implementing this option would require close cooperation among the Qingdao Hydrological Bureau, farmers, and technical specialists, as it will entail changes in land, fertilizer, and irrigation management and it may also necessitate limiting land use activities that are contributing to high nitrate losses.

Alternative integrated management options. To assess alternative solutions to control nonpoint source pollution, the computer model Nitrogen Leach and Economic Analysis Package (NLEAP) was applied. NLEAP estimates the nitrate leaching potential under agricultural crops as well as the potential impacts of nitrate leaching into groundwater. Closely linked with irrigation and fertilization processes, the local land use status is an important driver for the groundwater resource in the Dagu aquifer, both in terms of quantity and quality (Figure 11). ${ }^{22}$ The model was used to evaluate the impact of nitrate pollution in the Dagu

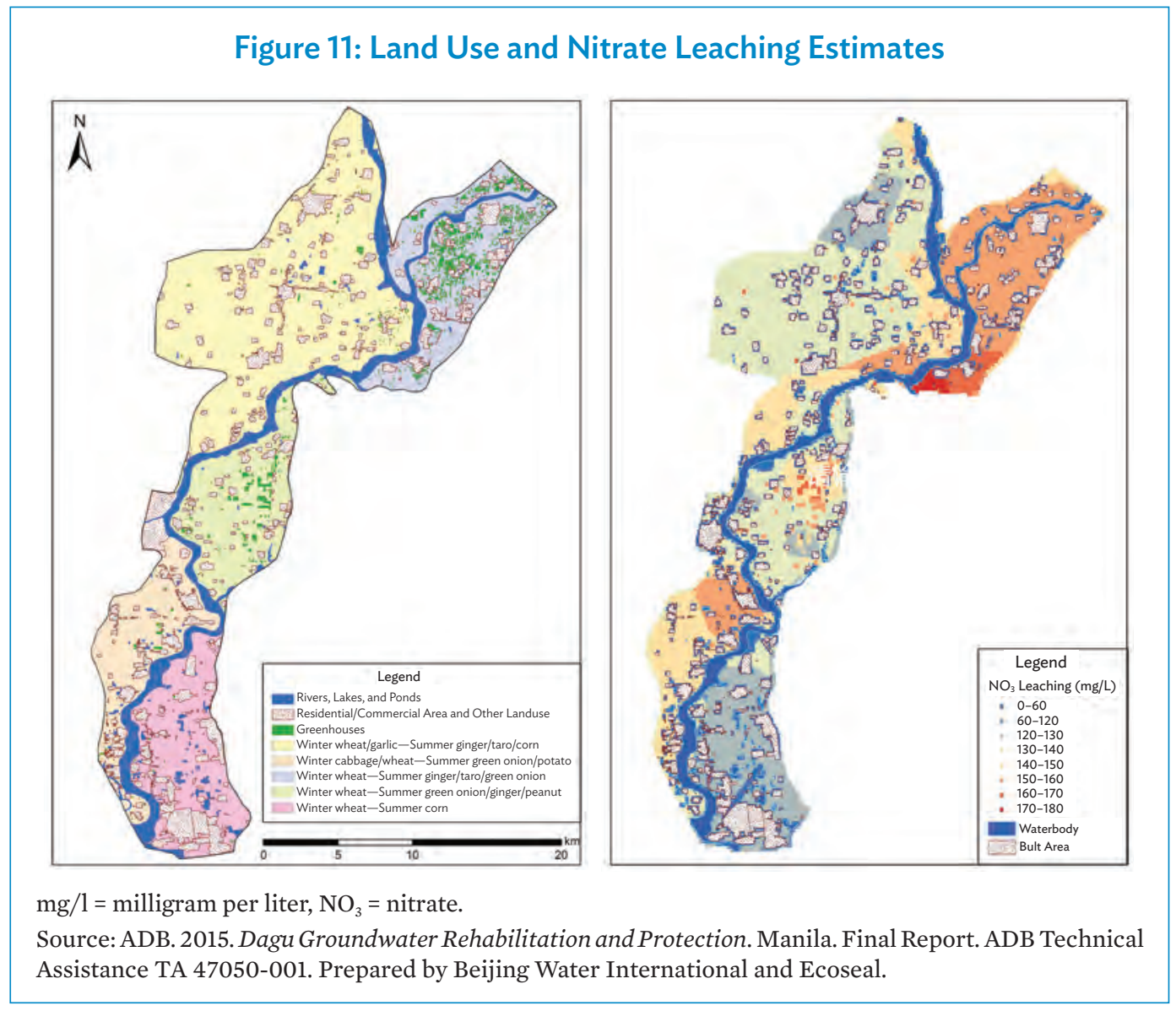

${ }^{22}$ A description of the NLEAP model is provided in the Appendix. 
aquifer under three simulated fertilizer application scenarios: (i) conventional, (ii) slowrelease fertilizer, and (iii) fertigation (i.e., the injection of fertilizers into the irrigation water). Of the three simulated scenarios, the slow-release fertilizer scenario appeared to provide the highest fertilizer usage efficiency. It also leaches the least amount of nitrate to the Dagu aquifer on an annual basis.

Under the conventional scenario, the nitrogen mass leached to the Dagu aquifer is estimated at 1,739 tons per year. The conventional scenario uses the highest quantity of fertilizer and, consequently, loses most fertilizer through leaching. Compared with the other two scenarios, fertilizer usage efficiency is lower. A larger portion of nitrogen is lost to runoff, emission, and volatilization, particularly so when fertilizers is applied early in the growing season.

The slow-release fertilizer scenario has the highest fertilizer usage efficiency among all simulated scenarios. The nitrogen mass leached to the Dagu aquifer is estimated at 1,302 tons per year. Compared with the conventional scenario, it uses the same amount of irrigation water but only requires half the fertilizer amount. Crop uptake is as high as the conventional scenario, yet its nitrate leaching rate is the lowest. However, slow-release fertilizers are more expensive than regular fertilizers, and the amounts need to be tested on local soils to attain optimal rates of application. Also, the efficiency of uptake by different crops is ambiguous, as this depends on the local soil and climatic condition, and needs to be established for all major crops (Figure 12). Hence, a thorough study employing various application rates is necessary before implementation can be rolled out on a regional scale.

Under the fertigation scenario, much less nitrogen is converted to soil residue and, thus, loses the least fertilizer among all scenarios. It also requires the least irrigation input and is the most water-saving scenario. However, the nitrate leaching to groundwater is highest of all scenarios, estimated at 3,153 tons per year. It also requires substantial investments in irrigation equipment and labor if implemented.

\section{Ginger from the Dagu River Basin}

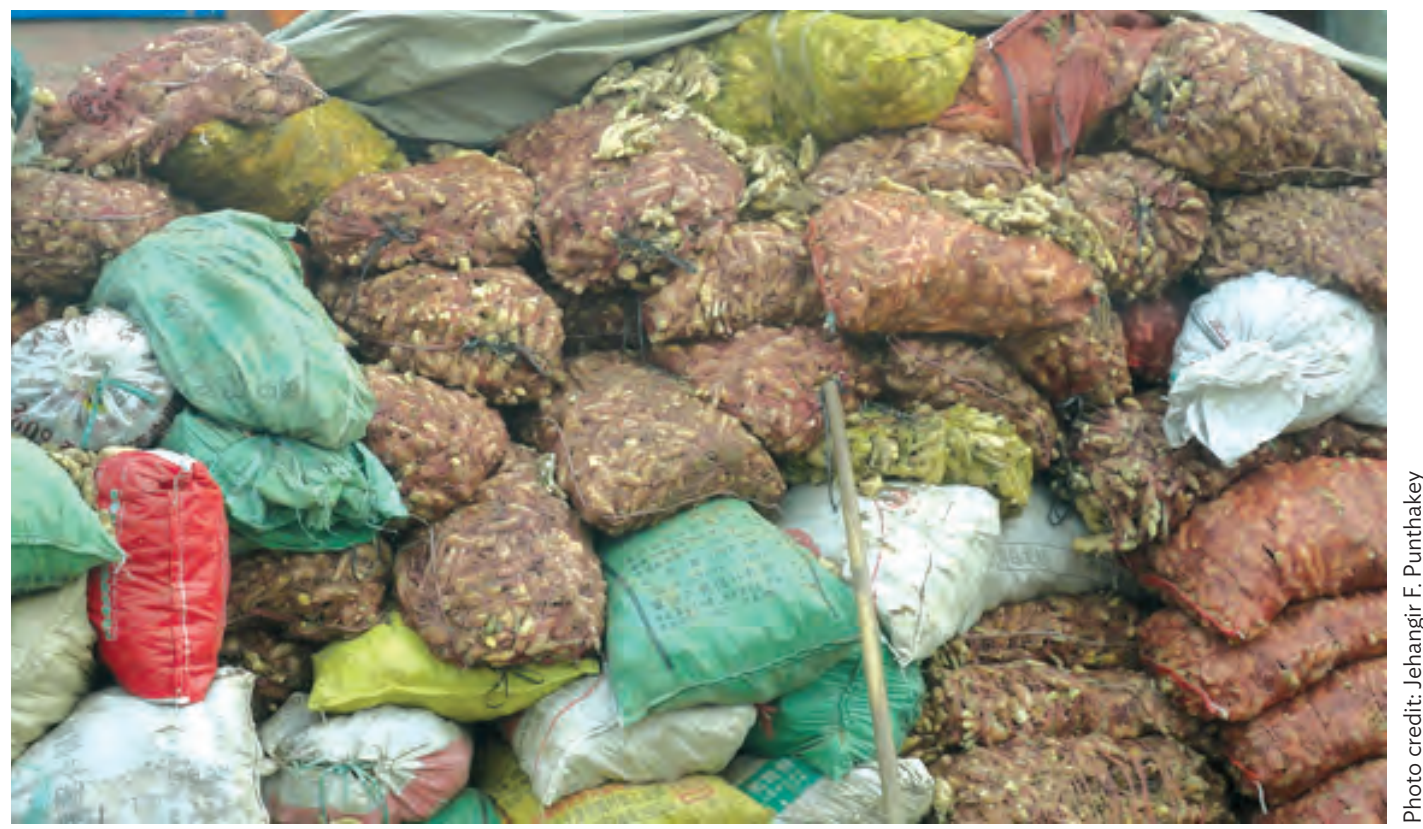




\section{Figure 12: Nitrate Leaching for Different Crops}
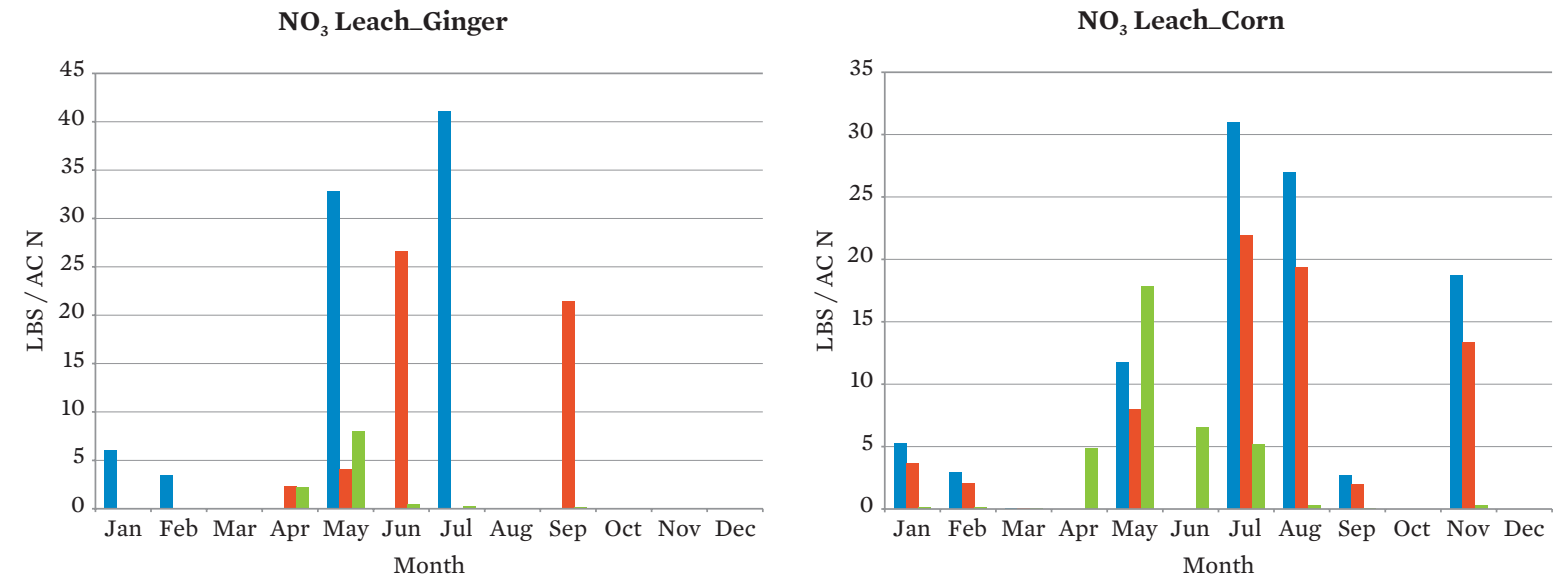

$\mathrm{NO}_{3}$ Leach_Potato

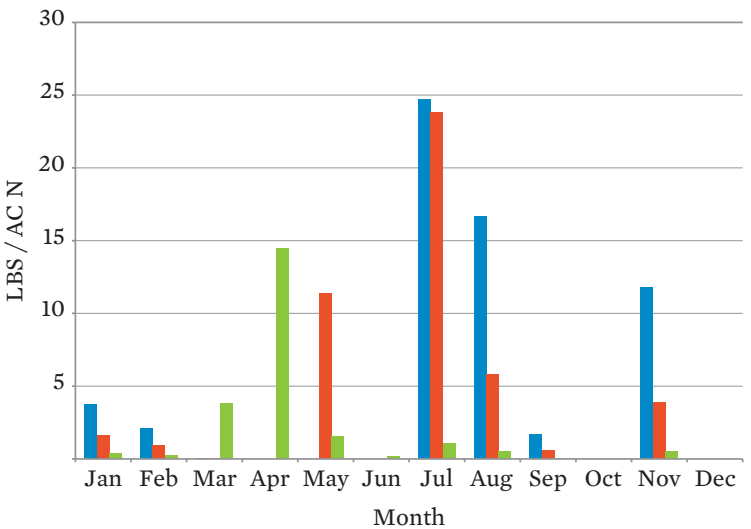

$\mathrm{NO}_{3}$ Leach_Chinese Cabbage

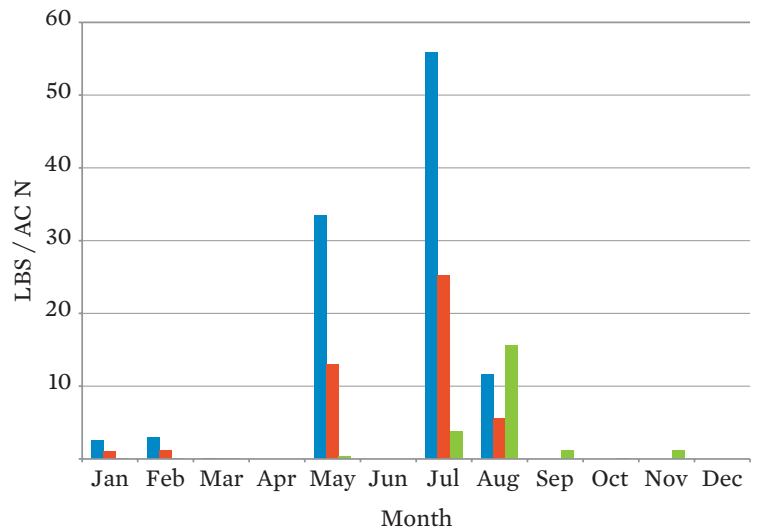

m Conventional fertilizer scenario $\quad$ - Slow-release fertilizer scenario $\quad$ Fertigation scenario

$\mathrm{AC}=$ acre, $\mathrm{LBS}=$ pounds, $\mathrm{N}=$ nitrate, $\mathrm{NO}_{3}=$ nitrate.

Source: ADB. 2015. Dagu Groundwater Rehabilitation and Protection. Manila. Final Report. ADB Technical Assistance TA 47050-001. Prepared by Beijing Water International and Ecoseal. 


\section{Main Findings: Information Key to Decision Making}

$\mathrm{T}_{\mathrm{s}}^{\mathrm{h}}$ he data assessment and modeling exercise for the Dagu aquifer showed the complexity of achieving a good understanding of the processes affecting groundwater quantity and quality. It also illustrated that there is no such thing as a one-size-fits-all approach for sustainable groundwater resources management. Tailoring a package of adaptive management measures to the local hydrogeological condition and socioeconomic situation is a prerequisite for success. For the Dagu aquifer, which largely supports groundwater-irrigated agricultural development, a number of specific recommendations were provided to the Qingdao Municipal Government for consideration and informed decision making.

A comprehensive monitoring program for water levels and water quality parameters is essential for providing relevant inputs for the development of an integrated management plan for the Dagu aquifer, preferably combined with the application of groundwater and contaminant transport models. High-yielding agricultural wells should all be accounted for and installed with water meters. Such agricultural production wells, together with nonpumping observation wells, especially those in high-vulnerability zones of the Dagu aquifer, are preferably equipped with continuous measurement loggers for proper monitoring of water level and quality. The current legislation already requires farmers to secure a license for the construction of wells that would tap into groundwater supply for agricultural use exceeding $3,000 \mathrm{~m}^{3}$ per day.

The modeling exercise using NLEAP shows that the most promising option for managing nitrate nonpoint source pollution of groundwater is promoting the use of slow-release fertilizers. Unfortunately, farmers are under the misguided belief that fast-release and soluble fertilizers are more effective. The cost of slow-release fertilizers is still a deterrent to its wide application, albeit simulation results show that the cost of using slow-release fertilizers is only marginally higher than normal fertilizers. Promoting education and awareness programs designed to persuade farmers to shift to slow-release fertilizers has the potential to significantly reduce groundwater nitrate leaching. Such programs are preferably combined with and based on the experimental trials that are needed to determine the efficacy of these application rates.

Water scarcity in Qingdao Municipality and the dependence of agriculture on groundwater in the Dagu basin confirm the pressing need to control the extraction and restore the quality of groundwater in the Dagu aquifer. This includes promoting water efficiency and water-saving measures in the agriculture sector to reduce overextraction. The Qingdao Hydrological Bureau, together with the Department of Agriculture, has been advised to develop nutrient management plans for the various land use zones of the Dagu aquifer. Nutrient management plans should be developed for each of the nitrate hot spots and areas with similar land management practices. Such units should be classified considering soil types, crops, slopes, proximity to surface water sources, depth to groundwater, and thickness of the aquifer, among 
others. Given the heterogeneity of the Dagu aquifer, ideally it is recommended to delineate nitrate vulnerable zones where particular measures (restrictions potentially) may be needed. This could be more cost-effective than applying strict conditions across the whole aquifer.

This approach would also facilitate the effective dissemination of information to groups of farmers with specific land management practices and provide support regarding fertilizer choice as well as optimal rate, timing, and frequency of fertilizer applications. Finally, it would result in improved economic returns for farmers and reduced nutrient losses to groundwater. 


\section{APPENDIX Description of the Applied Software Packages}

\section{Hydro GeoAnalyst}

Hydro GeoAnalyst is an all-in-one groundwater and environmental data management system that stores and organizes environmental data, and helps to quickly create comprehensive analytical results that are reliable and easy to understand. The software package includes the tools required to effectively and efficiently manage large volumes of data and to make informed decisions about environmental and water resources. It is designed to handle routine tasks such as data interpretation, statistical analysis, geographic information system (GIS) mapping, data charting, and visualization within a single software platform to minimize the time and effort involved in the data communication and migration. Hydro GeoAnalyst operates as a desktop application based on Microsoft SQL Server technology, which enables internet-based server-client data communication.

All data records in Hydro GeoAnalyst are saved and referenced to a "station." A station is a unique real-world location at which data collection activities are performed. Most operations in the software package require the selection of one or more stations in the station list tab. Depending on the scope, a project may contain single or multiple station types, each with its own attributes. Typical examples of stations are boreholes, pumping wells, observation or monitoring wells, surface water observation points, and weather stations.

Stations are organized into station groups based on certain criteria such as locations, types, or purpose of the stations. Multiple layers of information can be assigned to a certain station. The information can be added, edited, or retrieved by selecting the "Station Data" item from the navigation panel located to the left of the main interface or by selecting the "Station Data" tab from the main data view panel. The "Station Data" tab provides access to all data related to a single station. Once a station is added to the project, detailed information on the station can be inserted, edited, or deleted through this tab. All data communications within Hydro GeoAnalyst are driven by queries. The most common are the system's built-in queries such as Station Groups and Station Data. It often becomes necessary for users to customize the queries so that the data can be filtered in a specific way. Queries can be constructed and executed through a module named "Query Builder" located in the "Tools/Query Builder" menu option. This module can help users design the SQL query string according to their needs, even if they have no previous experience with the SQL query language. This module also enables users to edit, delete, or retrieve previously saved queries.

There are three mapping modules in Hydro GeoAnalyst: Map Manager, Cross Section Editor, and 3D Explorer. Map Manager is a horizontal two-dimensional mapping module built on ESRI Map Objects technology. It is packed with GIS mapping features commonly used by the environmental industry. The main purpose of this module is to analyze and to present 
the spatial orientation of groundwater or borehole data. Cross Section Editor is a vertical 2-D mapping module designed for presenting geological and hydrogeological information as well as groundwater modeling domains. 3D Explorer is a 3-D visualization and animation component for displaying multiple cross sections in the form of fence diagrams. In addition, base maps can be displayed for relating the fence diagrams to surface features.

\section{Sources and References}

Waterloo Hydrogeologic. Hydro GeoAnalyst. https:/www.waterloohydrogeologic.com/hydro -geoanalyst/

\section{Nitrate Leaching and Economic Analysis Package}

The Nitrate Leaching and Economic Analysis Package (NLEAP) is a field-scale computer model developed to provide a rapid and efficient method of determining potential nitrate leaching associated with agricultural practices. It combines basic information concerning onfarm management practices, soils, and climate and then translates the results into projected nitrogen budgets and nitrate leaching below the root zone and to groundwater supplies. It further estimates the potential off-site effects of leaching. The program translates the usersupplied information into projected nitrogen budgets, potential nitrate leaching, economic impacts, and the potential side effects of nitrate- $\mathrm{N}$ leaching.

The NLEAP model was designed to answer questions regarding potential leaching of nitrate. The processes modeled include movement of water and nitrate, crop uptake, denitrification, ammonia volatilization, mineralization of soil organic matter, nitrification, and mineralization-immobilization associated with crop residue, manure, and other organic wastes.

NLEAP has three levels of analysis to determine leaching potential: an annual screening, a monthly screening, and an event-by-event analysis. The annual screening analysis may be used to indicate a potential for nitrate leaching. The monthly and event-by-event analyses can be used to demonstrate the effect of alternative management strategies on reducing the nitrate leaching potential.

The screening procedure uses a simplified annual water and nitrogen budget and is designed to give only a general estimate of the potential leaching of nitrate. The monthly budget analysis calculates leaching with consideration for the seasonal and monthly effects of precipitation, temperature, evapotranspiration, and farm management. The event-by-event analysis provides the best estimate of nitrate leaching. Its water and nitrogen budgets track the impacts of each precipitation, irrigation, fertilization, and tillage event on potential nitrate leaching. The event-based procedure is recommended for analysis of potential nitrate leaching to domestic water supply.

Validation testing on more than 50 sites across 10 states in the United States has shown the model can predict residual soil nitrates and nitrate leaching to within approximately 22-56 kilograms per hectare per year. 
Sources and References

United States Department of Agriculture, Natural Resources Conservation Service. Nutrient Management-Nitrogen. US Department of Agriculture, Agricultural Research Service (ARS), Great Plains Systems Research, Fort Collins, Colorado. http://www.nrcs.usda.gov/ wps/portal/nrcs/detailfull/national/technical/ecoscience/mnm/?cid=stelprdb1044740

R. F. Follet, D. R. Keeney, and R. M. Cruse, eds. 1991. Managing Nitrogen for Groundwater Quality and Farm Profitability. Madison, WI: Soil Science Society of America. https:// dl.sciencesocieties.org/publications/books/tocs/acsesspublicati/managingnitroge Contains the documentation for processes modeled in NLEAP.

J. A. Delgado, P. M. Gagliardi, D. Neer, and M. J. Shaffer. 2010. Nitrogen Loss and Environmental Assessment Package with GIS Capabilities (NLEAP-GIS 4.2): User Guide. Washington, DC: United States Department of Agriculture, Agricultural Research Service. https://www.ars. usda.gov/ARSUserFiles/30121000/NitrogenTools/NLEAP_GIS_4_2_Manual_Nov_29_2010 .pdf

A standardized training workbook for the United States Department of Agriculture Natural Resources Conservation Service was developed by model leaders and national coordinators. A detailed training handbook is also available. 


\section{Water Resources Protection and Informed Decision Making An Example of the Dagu Aquifer in Qingdao, People's Republic of China}

Water security is a key priority for Asia-and the People's Republic of China is no exception. Local governments are struggling to ensure a water-secure future for their residents. Industries, farmers, and domestic water users are demanding reliable water supplies to sustain economic growth and food production. Moreover, uncertainties due to climate change pose critical challenges. The Asian Development Bank supported the Qingdao Municipal Government in preparing a groundwater resources plan for the Dagu aquifer in Shandong Province, and this report details the assessments and modeling technologies applied in the case study. Find out how these technologies, methodologies, and information may offer valuable lessons to other local governments when planning and making decisions about water security.

\section{About the Asian Development Bank}

ADB's vision is an Asia and Pacific region free of poverty. Its mission is to help its developing member countries reduce poverty and improve the quality of life of their people. Despite the region's many successes, it remains home to a large share of the world's poor. ADB is committed to reducing poverty through inclusive economic growth, environmentally sustainable growth, and regional integration.

Based in Manila, ADB is owned by 67 members, including 48 from the region. Its main instruments for helping its developing member countries are policy dialogue, loans, equity investments, guarantees, grants, and technical assistance.

\section{Securing Water, Sustaining Futures}

